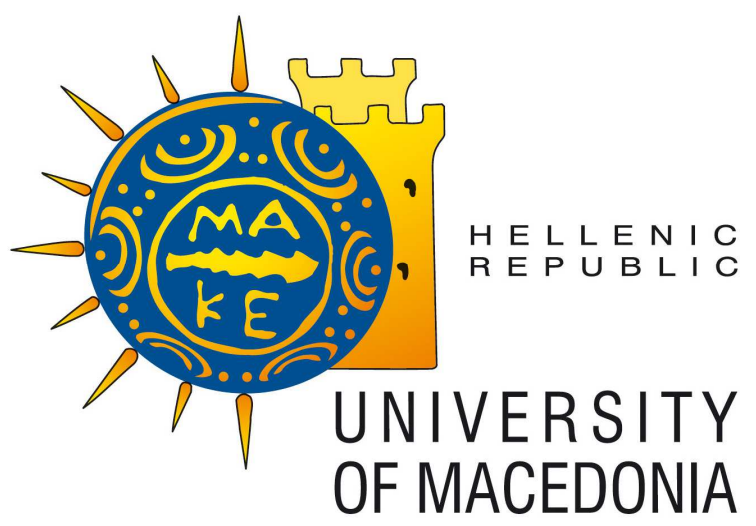

ISSN 1791-3144

\author{
University of Macedonia \\ Department of Economics
}

\author{
Discussion Paper Series
}

\title{
Another look at Calendar Anomalies
}

Evanthia Chatzitzisi, Stilianos Fountas and Theodore Panagiotidis

\section{Discussion Paper No. 2/2019}

Department of Economics, University of Macedonia, 156 Egnatia str, 54006

Thessaloniki, Greece, Fax: + 30 (0) 2310891292

http://www.uom.gr/index.php?newlang=eng\&tmima $=3 \&$ categorymenu=2 


\title{
Another Look at Calendar Anomalies
}

Evanthia Chatzitzisi; Stilianos Fountas; Theodore Panagiotidis ${ }^{\ddagger}$

Department of Economics, University of Macedonia, Thessaloniki, Greece

\begin{abstract}
We employ daily aggregate and sectoral S\&P500 data to shed further light on the day-of-the-week anomaly using GARCH and EGARCH models. We obtain the following results: First, there is strong evidence for day-of-the-week effects in all sectors, implying that these effects are part of a wide phenomenon affecting the entire market structure. Second, using rolling-regressions, we find that significant seasonality represents a small proportion of the total sample. Third, using a logit setup, we examine the impact of four factors, namely recessions, uncertainty, trading volume and bearish sentiment on seasonality. We reveal that recessions and uncertainty have explanatory power for anomalies whereas trading volume does not.
\end{abstract}

Keywords: day-of-the-week effect, GARCH, calendar anomalies, S\&P500 Index, sectors, rolling regression, logit

*email mec16021@uom.edu.gr

${ }^{\dagger}$ Corresponding author, email sfountas@uom.gr

łemail tpanag@uom.edu.gr

The authors are grateful to anonymous referees for helpful comments and suggestions. 


\section{Introduction}

Calendar anomalies are phenomena that are difficult to rationalize (Thaler 1987). Calendar anomalies such as the day-of-the-week effect and the weekend effect cannot be justified in standard asset pricing models, such as, the Capital Asset Pricing Model (CAPM) and the Arbitrage Pricing Theory (APT). Essentially, evidence for calendar anomalies represents a challenge to the Efficient Market Hypothesis (EMH) and has stimulated the interest of economists for many years.

An extensive amount of empirical work has been devoted to the examination of anomalies in the stock markets. The history of the analysis of day-of-the-week effects begins nearly a century ago. Following the pioneering work of Fields 1934, subsequent studies focused on the weekend effect and the Monday-Friday relationship. The increasing number of indexes from different countries and the increased datasets available put this topic under the spotlight. Noteworthy studies are those of Fama 1965, Cross 1973, French 1980, Gibbons and Hess 1981, Keim and Stambaugh 1984, Prince 1982, Rogalski 1984, Solnik and Bousquet 1990 and Choudhry 2000. In the late 1980s, despite the vast majority of literature backing the existence of anomalies, Connolly 1989 argued that such phenomena actually disappeared after 1975. Coutts and Hayes 1999, Steeley 2001 and Mehdian and Perry 2001 advocated the forementioned theory. The provided evidence cast doubts upon the stability of the phenomena and argue in favour of the evolving nature of the latter. To account for sample selection bias, Alagidede and Panagiotidis 2009 and Zhang et al. 2017, within a rolling framework, demonstrated that the phenomenon is not constant. A selected set of studies concerning both market wide indexes and sector-specified ones are presented in the Table 10 in the Appendix.

We focus on the day-of-the-week effect which implies that some days of the week exhibit systematically higher or lower returns compared to the others. Our contribution to the existing literature is twofold. First, we test for day-of-the-week effects using both aggregate (S\&P500 Index) and sectoral data in a long time period extending from September 11, 1989 to January 6, 2017. We investigate whether the anomalies found in the aggregate index have a particular pattern that is also present in the disaggregated sectors or whether they are part of a wider phenomenon characterising the entire market. Second, we test for the impact of various market factors (recession, uncertainty, trading volume and bearish sentiment) on the presence of daily abnormalities. To our knowledge, this is the first study to examine which market conditions can be viewed as drivers of calendar anomalies, within a logit specification.

The existing literature on the robustness and the stability of the day-of-the-week effect is rather limited. Furthermore, to the best of our knowledge, there is no literature examining the determinants of the seasonality in stock returns. Previous empirical studies examining similar issues that relate to the robustness of seasonal effects in asset returns include Sullivan et al. 2001, Hansen et al. 2005 and Bampinas et al. 2016. Sullivan et al. 2001 attempted to answer whether calendar anomalies are the outcome of data mining supporting that previous studies had been using the same data set to formulate and test hypotheses. They conclusively found that although nominal $p$-values of individual calendar anomalies were extremely significant, once all universe of calendar anomalies was considered, the anomalies detected lost their strength. Hansen et al. 2005 claim that the seasonality phenomenon has diminished in the late 1980s (with the exception of small-cap stock indices) inspected the time path of $p$-values that account for data-mining biases and found significant calendar effects only in specific sub-samples of DJIA returns and standardized returns during the 
20th century. Bampinas et al. 2016 used rolling-regression techniques and examined daily seasonality at the European real estate sector. They found absence of persistent day-ofthe-week effects. The above three studies looked at the issue of lack of persistence in return seasonality but did not attempt to examine the determinants of the seasonality phenomenon.

We provide a number of results: First, we find strong evidence of the day-of-week effect in both aggregate and sectoral S\&P500 index data. Second, using rolling regression techniques, we show that the day-of-the-week anomaly is not a stable phenomenon, but rather an evolving one that can be met only in 1 out of 5 (rolling) regressions. Third, the logit estimations indicate that out of four potential market determinants of the day-of-the-week effect, recessions and uncertainty are the most significant determinants. Our findings provide support to the efficient market hypothesis.

The rest of this paper is organized as follows. Section 2 describes the data set, Section 3 presents the econometric methodology, Section 4 reports the findings and finally, Section 5 provides some concluding remarks and implications on the usefulness of active trading strategies pursued by portfolio managers and traders.

\section{Data}

This study utilizes return series for the S\&P500 Index, together with 10 of its sectors namely Consumer Discretionary, Consumer Staples, Energy, Financials, Health Care, Industrials, Information Technology, Materials, Telecommunication Services and Utilities ${ }^{2}$. The closing price data used span from September 11, 1989 to January 6, 2017. The data frequency is daily allowing for testing day-of-the-week effects. The returns for each day, $t$, is computed as the first logarithmic differences:

$$
r_{t}=\ln \left(P_{t}\right)-\ln \left(P_{t-1}\right)
$$

where $P_{t}$ is the closing price of the index for day $t$. The series exhibit some discontinuities, mainly on holidays 4 . To enable data to be purged from the holiday effect, linear interpolation is implemented. This method delivers a 5-day sample for each week excluding the weekend where the stock market is closed. This step facilitates the subsequent procedure of rolling regression, where the sample rolls five days per time (weekly window).

Table 1 summarizes the descriptive statistics for the entire sample. All indices exhibit positive mean returns. The highest mean is observed for the Health Care sector while Telecommunication Services is the sector with the lowest mean returns. Concerning unconditional volatility, Financials holds the highest value and Consumer Staples the lowest. All indices are negatively skewed, but Financials, Information Technology, and Telecommunication Services. All series are found to be leptokurtic. The Jarque-Bera statistic indicates that none of them are normally distributed at the $1 \%$ level. Unit root (ADF) and stationarity (KPSS) tests confirm the stationarity of the return series.

\footnotetext{
${ }^{1}$ We focus on 10 out of a total of 11 sectors, excluding the Real Estate sector, which has been secluded from Financials post-September 16, 2016, due to lack of data.

${ }^{2}$ This categorization is based on the industry taxonomy of the Global Industry Classification Standard (GICS).

${ }^{3}$ Provided upon request from the S\&P Dow Jones Indices

${ }^{4}$ Discontinuities were observed in the data set on regular public holidays: Christmas, Thanksgiving, Easter, Independence Day, New Year's Eve, Labor Day, Birthday of Martin Luther King, Jr, Memorial Day and President's Day and on irregular market closures (e.g. on days following September 11, 2001).
} 
Table 1 Summary statistics for returns

\begin{tabular}{lccccccccc}
\hline & Mean & Max & Min & $\begin{array}{c}\text { Std. } \\
\text { Dev. }\end{array}$ & Skewness Kurtosis $\begin{array}{c}\text { Jarque- } \\
\text { Bera }\end{array}$ & $\begin{array}{c}\text { ADF } \\
\text { (constant, } \\
\text { no trend) }\end{array}$ & $\begin{array}{c}\text { KPSS } \\
\text { (constant, } \\
\text { no trend) }\end{array}$ \\
\hline $\begin{array}{l}\text { Consumer } \\
\begin{array}{l}\text { Discre- } \\
\text { tionary }\end{array}\end{array}$ & 0.0003 & 0.12315 & -0.101 & 0.012 & -0.06 & 10.09 & $14948.7^{* * *}$ & $61.65^{* * *}$ & 0.07 \\
$\begin{array}{l}\text { Consumer } \\
\text { Staples }\end{array}$ & 0.00031 & 0.08836 & -0.09296 & 0.009 & -0.172 & 11.26 & $20275.07^{* * *}-63.04^{* * *}$ & 0.15 \\
$\begin{array}{l}\text { Energy } \\
\text { Financials }\end{array}$ & 0.00027 & 0.16961 & -0.16884 & 0.015 & -0.258 & 14.66 & $40478.61^{* * *}-65.48^{* * *}$ & 0.07 \\
$\begin{array}{l}\text { Health } \\
\text { Care }\end{array}$ & 0.00022 & 0.17201 & -0.1864 & 0.017 & 0.047 & 19.53 & $81156.46^{* * *}-88.11^{* * *}$ & 0.17 \\
$\begin{array}{l}\text { Industrials } \\
\text { Information }\end{array}$ & 0.00028 & 0.11712 & -0.09174 & 0.011 & -0.141 & 8.77 & $9926.66^{* * *}-52.36^{* * *}$ & 0.17 \\
$\begin{array}{l}\text { Technology } \\
\text { Materials }\end{array}$ & 0.00034 & 0.16077 & -0.10008 & 0.016 & 0.141 & 8.5 & $9015.33^{* * *}-62.08^{* * *}$ & 0.12 \\
$\begin{array}{l}\text { Telecom } \\
\text { Services }\end{array}$ & 0.00019 & 0.12473 & -0.12933 & 0.014 & -0.216 & 10.58 & $17103.57^{* * *}-83.27^{* * *}$ & 0.02 \\
Utilities & $0.58 \mathrm{E}-05$ & 0.12923 & -0.10318 & 0.013 & 0.042 & 10.4 & $16275.93^{* * *}-62.17^{* * *}$ & 0.12 \\
S\&P500 & 0.00026 & 0.10957 & -0.0947 & 0.011 & -0.26 & 12.36 & $26117.79^{* * *}+63.66^{* * *}$ & 0.12 \\
\hline
\end{tabular}

Notes: $* * *$ denotes significance at the $1 \%$ level. Jarque-Bera test checks the rejection or not of the null hypothesis of $H_{0}$ : normally distributed returns against the alternative of $H_{a}$ : not normally distributed. ADF is the Augmented Dickey Fuller statistic which tests for the presence of a unit root with $H_{0}$ : returns have a unit root. KPSS is the Kwiatkowski-PhillipsSchmidt-Shin statistic with the null hypothesis $H_{0}$ : stationary returns. 
We will also use four other variables as potential determinants of the day-of-the-week effects. These are 1) the NBER's recession indicator, 2) the News-based Economic Policy Uncertainty index, 3) the Trading volume index ${ }^{5}$ and 4) the Bearish sentiment index. Further details are available in Table 2 below.

\section{$3 \quad$ Econometric Methodology}

\subsection{GARCH models}

Early studies discussing day-of-the-week phenomena employed descriptive statistics. They focused on the first four moments of the unconditional distribution of returns. Unconditional tests like the ANOVA setting and Kruskal-Wallis were among the most preferred ones to test for daily differences. Some studies use OLS and regress stock returns on five daily dummies. However, the traditional OLS methodology has two main drawbacks. First, the error term may be autocorrelated leading to false standard error estimates and misleading inference. In order to account for autocorrelation in the errors, the inclusion of lagged returns in the mean equation was used. Second, OLS assumes constancy of error variance, an unrealistic assumption given the vast literature backing its time-dependence. Hence, we model the conditional variance of shocks to returns as time varying with a GARCH model. This type of model controls for the observed heteroskedasticity and captures the phenomenon of volatility clustering. The models can be written as Eqs. (2)-(5) below:

$$
\begin{gathered}
r_{t}=\lambda_{1} d_{1 t}+\lambda_{2} d_{2 t}+\lambda_{3} d_{3 t}+\lambda_{4} d_{4 t}+\lambda_{5} d_{5 t}+\sum_{i=1}^{k} \alpha_{i} r_{t-i}+e_{t} \\
e_{t} \mid \Omega_{t-1} \sim t \text { or } G E D\left(0, h_{t}\right) \\
h_{t}=\omega+a e_{t-1}^{2}+\beta h_{t-1} \\
\log \left(h_{t}\right)=\omega+\beta \log \left(h_{t-1}\right)+\alpha\left(\frac{\left|e_{t-1}\right|}{\sqrt{h_{t-1}}}-\sqrt{\frac{2}{\pi}}\right)+\gamma \frac{e_{t-1}}{\sqrt{h_{t-1}}}
\end{gathered}
$$

where $r_{t}$ is the continuously compounded index return, $d_{1 t}, d_{2 t}, \ldots, d_{5 t}$ are daily dummy variables for Monday, Tuesday, Wednesday, Thursday and Friday respectively, each taking the value of 1 on the respective day and 0 otherwise, $\lambda_{1}, \lambda_{2}, \ldots, \lambda_{5}$ are the corresponding coefficients, $e_{t}$ is the error term and $h_{t}$ is the conditional variance. The number $k$ of the autoregressive terms is determined by the Akaike Information Criterion (AIC). Eq. (2) shows the determination of returns and Eq. (3) two specifications of the conditional distribution of the errors, Student's $t$ and Generalized Error Distribution (GED). We employ two alternative versions of model specification for $h_{t}$, the symmetric $\operatorname{GARCH}(1,1)$ introduced

\footnotetext{
${ }^{5}$ In this data series, some detrending would be advisable to prelude in order to remove variability elements and obtain a smoothed measure. For this reason, each daily observation is divided by the average volume of the week, see Fishe et al. 1993. The resulting index essentially measures whether the daily volume is above or below the weekly average, by whether the observation is above or below unity. This detrended index is then used in our analysis.
} 





independently by Bollerslev 1986 and Taylor 1987 and the asymmetric EGARCH(1,1) proposed by Nelson 1991, given in Eqs. (4) and (5) respectively. Coefficients $\alpha$ and $\gamma$ in Eq. (5) have the following meaning: the first coefficient captures the so-called magnitude effect, i.e., it measures the effect of the size of a shock on the conditional variance. The second coefficient is the asymmetry coefficient which measures the effect of the sign of a shock on the conditional variance. In practice, $\operatorname{GARCH}(1,1)$ and $\operatorname{EGARCH}(1,1)$ are sufficient to capture the volatility clustering in the data.

\subsection{Rolling-regressions}

Traditionally, GARCH models have been estimated using the full sample. On the basis of the conflicting results obtained, it is important to examine whether the findings are robust or sample dependent. Estimating model coefficients through a rolling window has been a common practice in testing for calendar anomalies. This allows testing for the stability of the model's coefficients through time.

In our case, the rolling window and step size are fixed at 260 (which is approximately a period of a year) and 5 weekdays, respectively, leading to a total of 1,375 windows. The first regression relies on the sample with observations 1-260, the second 6-265, the third 11-270, and so on. On the basis of the minimum value of AIC, we find that for all sectors, the EGARCH $(1,1)$ model is the preferred specification. It is worth mentioning that we let the length of the autoregressive part free to vary through iterations according to the AIC. This property allows a more efficient management of the data and induces a dynamic structure to the rolling technique.

We will use a measure ${ }^{6}$ of the intensity of day-of-the-week effects in each sector. This measure is defined, for each weekday, as the percentage of the statistically significant (at the $5 \%$ level) coefficients out of the total number of regressions performed:

$$
\begin{aligned}
i=\% \text { of statistically significant (at } 5 \% \text { level) coefficients } \\
\qquad=\frac{\text { number of statistically significant (at } 5 \% \text { level) coefficients }}{\text { total number of regressions performed }}
\end{aligned}
$$

As this quantity is a single number, cross-sector comparisons can be generated.

\subsection{Logit models}

Logit and probit7 models belong to a wide class known as limited dependent variable models, where the qualitative information of the dependent variable can be coded either as finite integers or as binary outcomes. They are designed to overcome two major drawbacks of the latter: 1) Fitted probabilities always lie in the [0,1] interval and 2) the partial effect of any of the explanatory variables is not constant across individuals. These models ensure the validity of those properties through a transformed $F$ :

$$
P_{i}=\operatorname{Pr}\left(Y_{i}=1\right)=F\left(\beta_{1}+\beta_{2} x_{2 i}+\beta_{3} x_{3 i}+\ldots+\beta_{k} x_{k i}+u_{i}\right)
$$

\footnotetext{
${ }^{6}$ We have encountered the exact measure in Bampinas et al. 2016, as well as a variant in Zhang et al. 2017, which allows comparisons across different rolling windows.

'Probit is a portmanteau word coming from probability + unit. Logit is a term that is borrowed by analogy from the famous and similar probit model.
} 
In case of logit models, $F$ equals the logistic function, which is the cumulative distribution function (cdf) for a standard logistic random variable:

$$
F(z)=\frac{e^{z}}{1+e^{z}}=\frac{1}{1+e^{-z}}
$$

with $F$ being a strictly increasing function, satisfying the following properties: as $z \rightarrow-\infty$, $F \rightarrow 0$ while as $z \rightarrow+\infty, F \rightarrow 1$.

Due to the nonlinear nature of $F$, a marginal effect of a change of any explanatory variable on the dependent variable, differs across entities. In order to get a single value representing the whole sample, the Average Marginal Effects (AME) are used. The formula for continuous variables is:

$$
A M E_{j}=\beta_{j} \frac{1}{n} \sum_{k=1}^{n} F\left(\beta X_{k}\right)
$$

and for the dummy variables:

$$
A M E_{j}=\frac{1}{n} \sum_{k=1}^{n}\left(F\left(\beta X_{k} \mid X_{j k}=1\right)-F\left(\beta X_{k} \mid X_{j k}=0\right)\right)
$$

In our analysis, we will examine whether the existence of daily anomalies can be explained by various factors. The results are based on the significance and direction of the effects, i.e. whether they are linked to negative or positive returns. To further clarify the situation, the procedure is described in the following steps. First, for each weekday, two-level factor variables are constructed indicating the presence or absence of significant day-of-the-week effects in the rolling time periods. The procedure is now split into three strands. The first factor variable is defined to be unity for cases where significant daily anomalies existed, associated with daily negative mean returns and zero otherwise. Likewise, the second dummy variable is one for significant daily anomalies linked to positive mean returns and zero otherwise. The third and last factor variable is an extended version of the previous two, pointing out significant day-of-the-week effects either bonded to positive or negative mean returns. Let the three versions of probabilities be labeled psig $_{n e g}$, psig $g_{\text {pos }}$ and psig respectively:

$$
\begin{aligned}
& \text { psig }_{\text {neg }}= \begin{cases}1 & \text { if } p-\text { value }<0.05 \quad \& \quad \text { coef }<0, \\
0 & \text { else }\end{cases} \\
& \text { psig }_{\text {pos }}= \begin{cases}1 & \text { if } p-\text { value }<0.05 \quad \& \quad \text { coef }>0, \\
0 & \text { else }\end{cases}
\end{aligned}
$$

and

$$
\text { psig }= \begin{cases}1 & \text { if } p-\text { value }<0.05 \\ 0 & \text { else }\end{cases}
$$

In the logit estimation setup, we employ each of these factor variables separately as the dependent variable with explanatory variables being: the NBER's recession indicator, the uncertainty index, the detrended trading volume and the bearish sentiment index. Average marginal effects are then computed to determine whether anomalies can be explained by these four drivers. 


\section{Empirical Results}

\subsection{GARCH models}

We first estimate the models using the full sample. For model selection, four versions of information criteria are considered: AIC, SIC and their modified (healthy) versions HAIC and HSIC. Each of these criteria is applied to two GARCH-type models, $\operatorname{GARCH}(1,1)$ and EGARCH $(1,1)$ and two different error distributions, $t$ and GED. All criteria suggest the use of the $\operatorname{EGARCH}(1,1)$ model instead of the symmetric $\operatorname{GARCH}(1,1)$ model for the S\&P500 Index and all of its 10 sectors. EGARCH model with GED distributed errors emerges as the preferred choice also in Bampinas et al. 2018 (for the individual stocks in the S\&P 1500 universe when non-negativity and stationarity constraints in the conditional variance are imposed, after 11520 regressions).

Table 3 presents the estimated model for each index, assuming a GED distribution for the conditional distribution of the innovations. The top part of the table consists of the estimated coefficients of the mean equation. The length of the autoregressive part is determined individually for each sector to minimize the AIC. Lengths from 0 up to 5 were considered. Monday coefficients are all positive and statistically significant except for the Materials sector with a p-value nearly exceeding the $10 \%$ level of significance, providing support to studies suggesting the presence of a "reverse" Monday effect 8 . Tuesday coefficients are also positive in all cases but significant for half of the sectors. Similar results are found for Wednesday. The coefficients are all positive but significant ones emerge for 6 sectors and the S\&P500. Positive and significant coefficients for Thursday are revealed for Consumer Staples, Health Care and Industrials. Two of the sectors, namely Financials and Utilities exhibit negative expected returns but not significant. Friday results indicate a positive sign for all cases with significant results for Consumer Staples, Utilities and the S\&P500. The coefficients of Information Technology and Telecommunication Services are negative but not significant.

The bottom part of Table 3 contains information for the variance equation. The asymmetry term $\gamma$ is shown to be negative and statistically significant for all 10 sectors and the S\&P500 Index, supporting the choice of an asymmetric model to capture the leverage effects. The constant term $\omega$, is negative for all cases at the $1 \%$ level. Both $\alpha$ and $\beta$ coefficients are all positive and significant. Moreover, all estimated values for $\beta$ are below unity, signaling stationarity of conditional variances in all models. To confirm stationarity, three unit root tests are performed: augmented Dickey and Fuller 1979, Phillips and Perron 1988 and Zivot and Andrews 2002 with one break point. The results are not presented but available upon request. All unit root tests employed support stationarity of the conditional variance series at the $1 \%$ level, except for Zivot and Andrews 2002 unit root test in the Financials sector (the null hypothesis of a unit root is not rejected at the $10 \%$ level). In all cases, coefficient $\beta$ is close to 1 indicating considerable persistence in the conditional variance of the error term. At the bottom of Table 3, we also report results of the BDS and Li-Mak statistics which test for iid errors and remaining ARCH effects, respectively. These results show evidence for iid errors and absence of remaining $\mathrm{ARCH}$ effects in the majority of the cases.

\footnotetext{
${ }^{8}$ See for example Mehdian and Perry 2001, Brusa et al. 2003 and Liu and Li 2010
} 


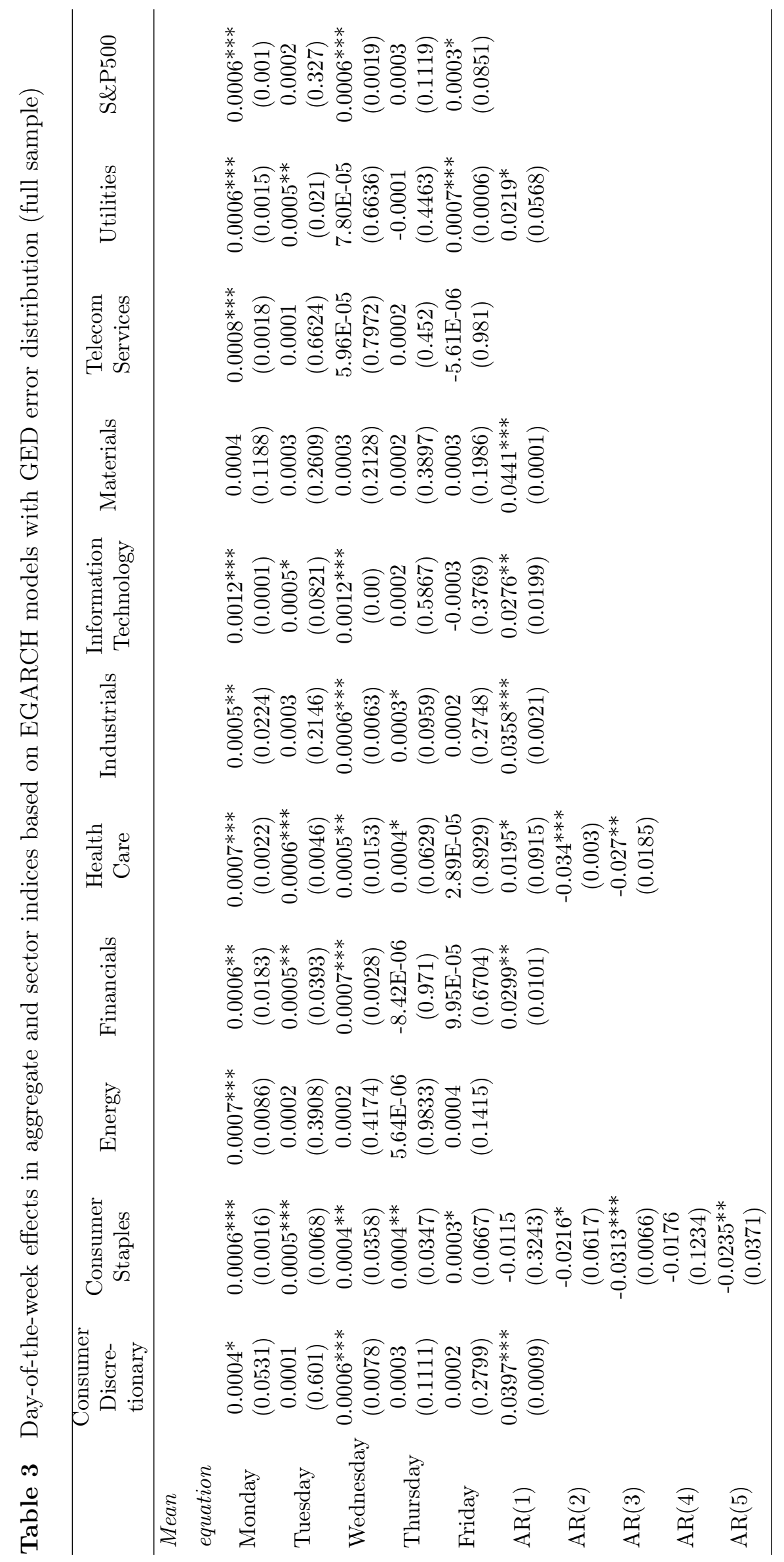




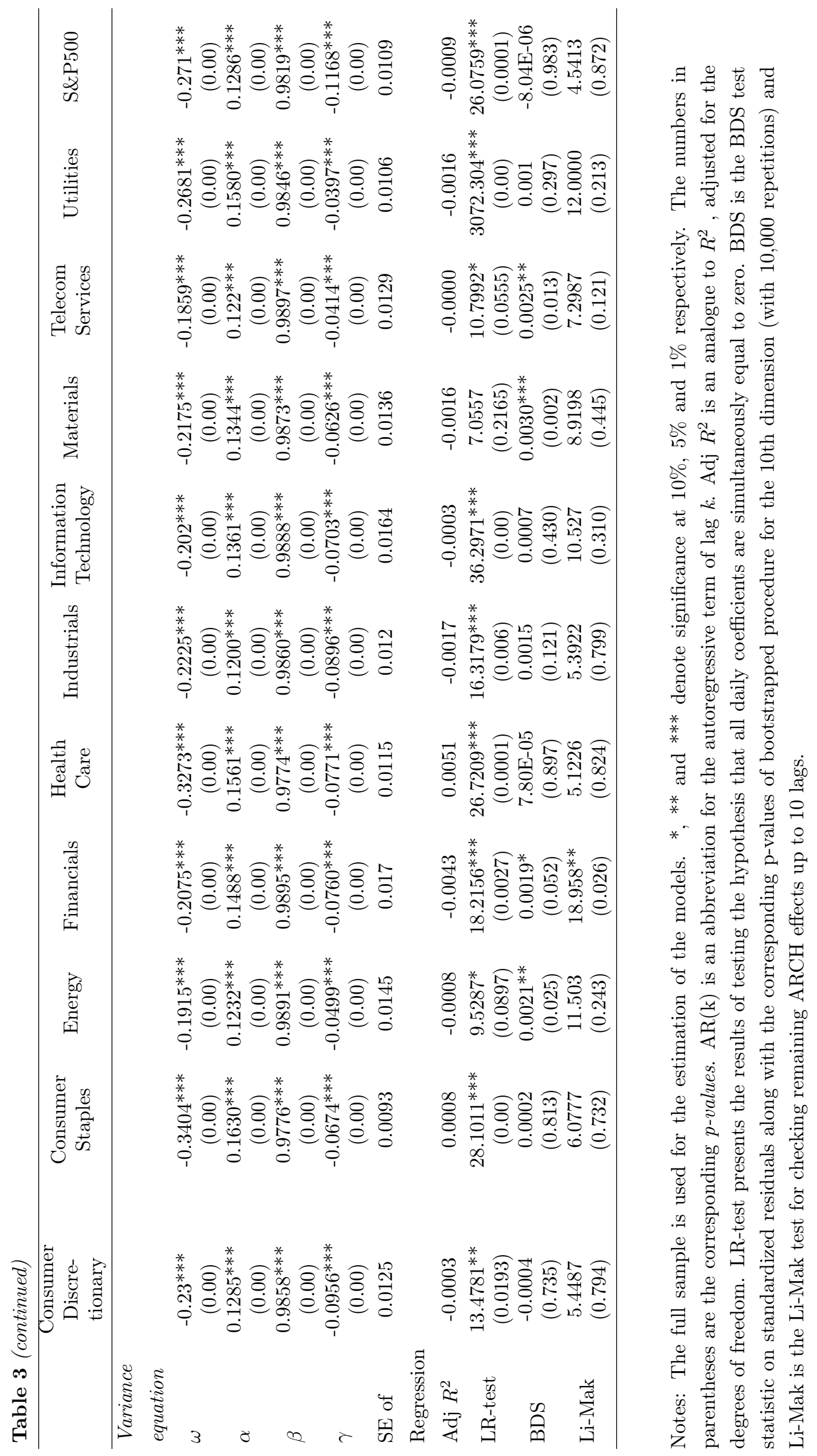




\subsection{Rolling Regressions}

The results of the EGARCH(1,1) model with student's $t$ and GED distributed disturbances, in a rolling framework, are presented in Tables 4 and 5 respectively.

EGARCH $(1,1)$ model with $t$-distributed innovations yields interesting results. Monday reaches the highest intensity among the 5 weekdays for 8 of 10 sectors and the S\&P500 Index except for the Consumer Staples and the Telecommunication Services sectors (where it reaches the second largest). The former is exposed to Friday anomalies to a greater extent while the latter to Wednesday anomalies. On the other hand, the weaker anomalies detected are those of Thursday for the S\&P500 Index accompanied by the following 4 sectors: Energy, Industrials, Telecommunication Services and Utilities. The remaining sectors share the weakest anomalies on Tuesday, Wednesday and Friday. Overall, we get significance above $20 \%$ of the rolling regressions on Monday in 5 out of the 11 cases.

EGARCH(1,1) model with GED distributed innovations leads to similar conclusions. The highest intensity of day-of-the-week effects among the 5 weekdays is observed on Monday for all cases except for the Consumer Staples, Information Technology and Telecommunication Services where it is found to be the second largest. The first of these sectors exhibit prominent Friday anomalies whereas the last two Wednesday anomalies. The weakest phenomena are on Thursdays for the S\&P500 Index and 4 of its sectors, namely Financials, Industrials, Telecommunication Services and Utilities. The remaining 6 sectors joined by two have lowest percentages on Tuesday, Wednesday and Friday. To sum up GED, we get above $20 \%$ significance of the rolling regressions on Monday in 4 out of the 11 cases.

Generally, GED yields higher percentage values than the $t$-distributed counterparts. For the two most documented anomalies those of Monday and Friday, the percentages range from 13.8 to 21.7 and 13.9 to 23.1 for Mondays and 5.7 to 15.3 and 7.1 to 19.1 for Fridays, for $t$-distribution and GED respectively. Moreover, cross-sector analysis emerges the Monday anomaly the strongest one in both cases. $t$-distribution offers a $21.7 \%$ in the Consumer Discretionary sector, while GED offers a generous $23.1 \%$ for the Energy sector.

Tables 4 and 5 also provide information about the sign of the significant patterns. The vast majority of the significant day-of-the-week effects are produced by positive coefficients with minimal deviations. Extreme cases are those of $43.5 \%$ and $40.4 \%$ (40.1\%, 36.7\% using GED) of the total set of significant Monday anomalies which are caused by negative coefficients for Materials and Financials sectors and 70.8\% (71.5\% in the GED) of Friday for the Information Technology sector. Finally, dominant positive coefficients causing the Friday effect are evident in the Utilities sector with a percentage of $86 \%$ (88\% using GED). Overall, most significant Monday coefficients tend to be positive.

These results have important implications for investors and market participants. Given our finding that seasonality is an evolving, rather than a stable, phenomenon, day-of-theweek effects are not as significant as originally thought. Hence, portfolio managers and traders would be unable to obtain profits by pursuing active strategies involving investment in sectoral indices. Our results have also interesting implications regarding the validity of the market efficiency hypothesis. In other words, our results provide support to the efficient market hypothesis as a long-run phenomenon. Other recent studies (Rösch et al. 2016) claim that market efficiency is time-varying as it relates to the funding liquidity that is available to investors. The empirical analysis provided by these authors indicate that market liquidity, as proxied by trading volume, would lead to less (if any) anomalies. 
Table 4 Percentage of significant coefficients in EGARCH rolling regressions using $t$-distribution

\begin{tabular}{|c|c|c|c|c|c|c|c|c|c|c|c|c|c|c|c|c|}
\hline & \multicolumn{3}{|c|}{ Monday } & \multicolumn{3}{|c|}{ Tuesday } & \multicolumn{3}{|c|}{ Wednesday } & \multicolumn{3}{|c|}{ Thursday } & \multicolumn{3}{|c|}{ Friday } & \multirow[t]{2}{*}{ NAs } \\
\hline & $\begin{array}{c}\% \\
\text { Sign. }\end{array}$ & $\begin{array}{c}\% \text { of } \\
\text { neg. } \\
\text { from } \\
\text { all } \\
\text { sign. }\end{array}$ & $\begin{array}{c}\% \text { of } \\
\text { pos. } \\
\text { from } \\
\text { all } \\
\text { sign. }\end{array}$ & $\begin{array}{c}\% \\
\text { Sign. }\end{array}$ & $\begin{array}{c}\% \text { of } \\
\text { neg. } \\
\text { from } \\
\text { all } \\
\text { sign. }\end{array}$ & $\begin{array}{c}\% \text { of } \\
\text { pos. } \\
\text { from } \\
\text { all } \\
\text { sign. }\end{array}$ & $\begin{array}{c}\% \\
\text { Sign. }\end{array}$ & $\begin{array}{l}\% \text { of } \\
\text { neg. } \\
\text { from } \\
\text { all } \\
\text { sign. }\end{array}$ & $\begin{array}{l}\% \text { of } \\
\text { pos. } \\
\text { from } \\
\text { all } \\
\text { sign. }\end{array}$ & $\begin{array}{c}\% \\
\text { Sign }\end{array}$ & $\begin{array}{c}\% \text { of } \\
\text { neg. } \\
\text { from } \\
\text { all } \\
\text { sign. }\end{array}$ & $\begin{array}{c}\% \text { of } \\
\text { pos. } \\
\text { from } \\
\text { all } \\
\text { sign. }\end{array}$ & $\begin{array}{c}\% \\
\text { Sign. }\end{array}$ & $\begin{array}{l}\% \text { of } \\
\text { neg. } \\
\text { from } \\
\text { all } \\
\text { sign. }\end{array}$ & $\begin{array}{c}\% \text { of } \\
\text { pos. } \\
\text { from } \\
\text { all } \\
\text { sign. }\end{array}$ & \\
\hline S\&P500 & 20.4 & 23.9 & 76.1 & 14 & 39.4 & 60.6 & 12.6 & 45.1 & 54.9 & 6.9 & 37.9 & 62.1 & 14.6 & 36.3 & 63.7 & 12 \\
\hline $\begin{array}{l}\text { Consumer } \\
\text { Discre- } \\
\text { tionary }\end{array}$ & 21.7 & 28.9 & 71.1 & 14.3 & 44.2 & 55.8 & 9.4 & 47.3 & 52.7 & 11.8 & 32.7 & 67.3 & 14.3 & 59.2 & 40.8 & 12 \\
\hline $\begin{array}{l}\text { Consumer } \\
\text { Staples }\end{array}$ & 13.8 & 6.8 & 93.2 & 11.7 & 26.7 & 73.3 & 6.5 & 15.7 & 84.3 & 8.3 & 15.8 & 84.2 & 15.3 & 37.9 & 62.1 & 15 \\
\hline Energy & 21.2 & 34.2 & 65.8 & 6.5 & 42.7 & 57.3 & 11.6 & 56.2 & 43.8 & 4.4 & 78.7 & 21.3 & 10.9 & 36 & 64 & 20 \\
\hline Financials & 21.1 & 40.7 & 59.3 & 7.3 & 39.6 & 60.4 & 11 & 35.8 & 64.2 & 8.5 & 76.9 & 23.1 & 9.1 & 47.2 & 52.8 & 9 \\
\hline Health Care & 21.5 & 14.6 & 85.4 & 16.2 & 37.7 & 62.3 & 10 & 20.3 & 79.7 & 8.9 & 27.9 & 72.1 & 5.8 & 25 & 75 & 29 \\
\hline Industrials & 18.2 & 35.6 & 64.4 & 7.4 & 22.5 & 77.5 & 15.7 & 43.5 & 56.5 & 4.1 & 36.8 & 63.2 & 12.5 & 42.4 & 57.6 & 14 \\
\hline $\begin{array}{l}\text { Information } \\
\text { Technology }\end{array}$ & 16.4 & 15 & 85 & 9.3 & 34.4 & 65.6 & 15.7 & 16.2 & 83.8 & 11.3 & 35.9 & 64.1 & 10.5 & 70.8 & 29.2 & 10 \\
\hline Materials & 15.2 & 43.5 & 56.5 & 12.1 & 58.7 & 41.3 & 7.7 & 50 & 50 & 7 & 71.9 & 28.1 & 5.7 & 47.4 & 52.6 & 20 \\
\hline $\begin{array}{l}\text { Telecom } \\
\text { Services }\end{array}$ & 17 & 12 & 88 & 13.7 & 42.6 & 57.4 & 18 & 54 & 46 & 7.3 & 43 & 57 & 9.5 & 45 & & 26 \\
\hline Utilities & 18.4 & 3.6 & 96.4 & 12.4 & 24.6 & 75.4 & 12.2 & 44.6 & 55.4 & 8.7 & 77.3 & 22.7 & 10.9 & 14 & 86 & 18 \\
\hline
\end{tabular}

Notes: The percentages reported are measured by Eq. (6) in the text. Rolling regressions are performed with rolling window set to 260 and step size set to 5 weekdays. In each case, the first number denotes the percent of significant coefficients out of the total number of rolling regressions. The second and third numbers following, present the percentage of negative and positive coefficients respectively out of the significant ones across all weekdays. The last column depicts the number of NAs derived out of a total of 1375 rolling regressions performed. (NAs were treated as insignificant results.) 
Table 5 Percentage of significant coefficients in EGARCH rolling regressions using GED distribution

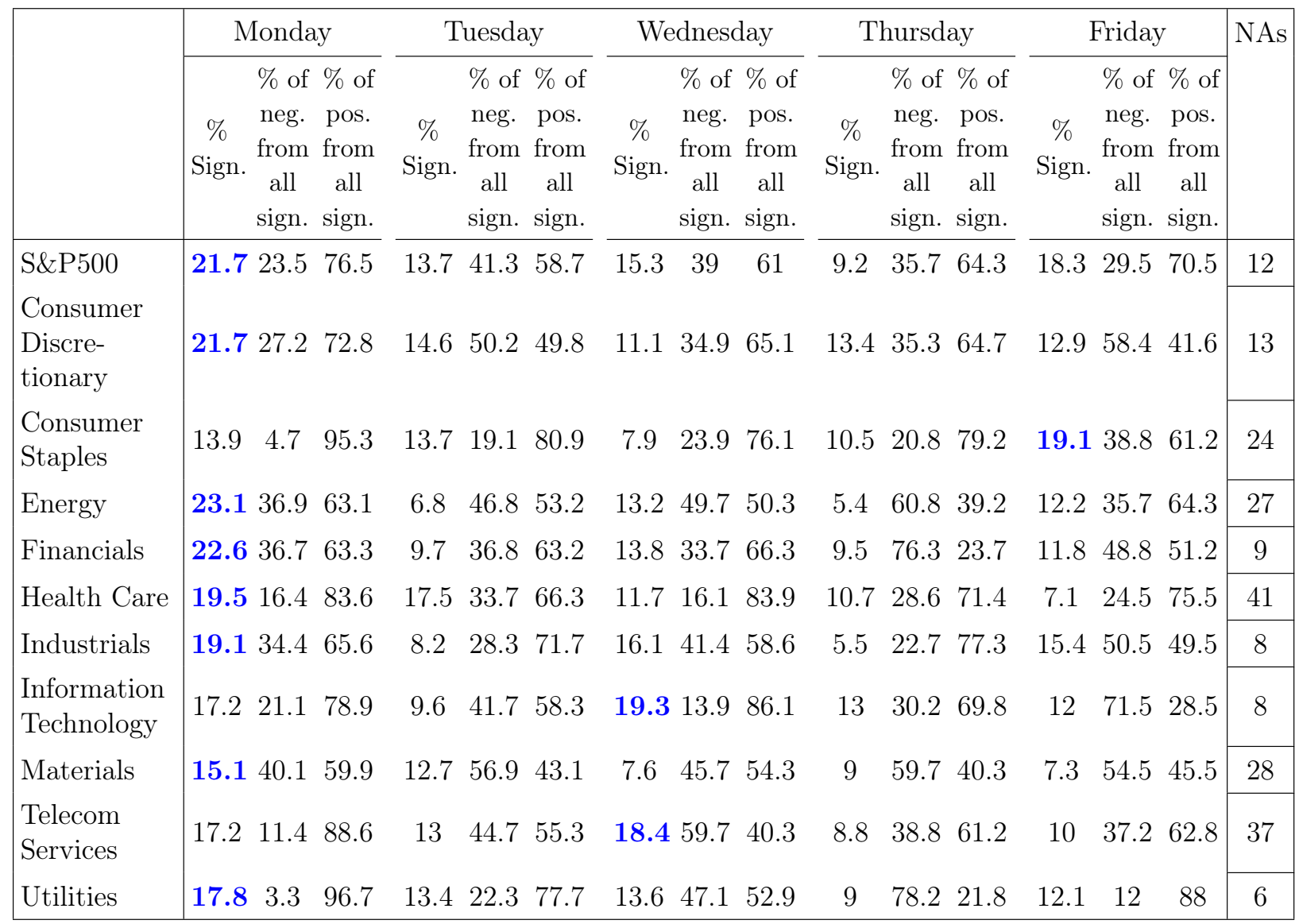

Notes: The percentages reported are measured by Eq. (6) in the text. Rolling regressions are performed with rolling window set to 260 and step size set to 5 weekdays. In each case, the first number denotes the percent of significant coefficients out of the total number of rolling regressions. The second and third numbers following, present the percentage of negative and positive coefficients respectively out of the significant ones across all weekdays. The last column depicts the number of NAs derived out of a total of 1375 rolling regressions performed. (NAs were treated as insignificant results.) 


\subsection{Drivers of seasonality}

This subsection investigates the drivers of the day-of-the-week effects obtained from the rolling-regression approach. In particular, we consider four factors: recession, uncertainty, trading activity and bearish sentiment as potential causes of the day-of-the-week effects. We follow two steps. First, the estimated coefficients and corresponding p-values are derived from the rolling regressions of the EGARCH models with a GED error distribution. We classify the obtained results in three groups depending on the sign of the average mean return (positive, negative or any sign). In the second step, we compute average marginal effects in a logit framework and display the results at Tables 7,8 and 9. Table 7 refers to group A (significant anomalies with negative mean returns), Table 8 to group B (significant anomalies with positive mean returns) and Table 9 to group $\mathrm{C}$ (significant anomalies with negative or positive mean returns).

\subsubsection{Recession}

We start with the results for the recession index (from the NBER, see Table 2). It is more likely in recession phases to experience Wednesday and Friday effects for the negative mean returns sample (Table 7) for the S\&P500 Index and 7 out of its 10 sectors. Concerning Monday effects, the results are similar, only weaker. These effects are significantly present for only 3 sectors, specifically for Financials, Health Care and Information Technology. The associated marginal effects range from $5 \%$ for the second one to around $20 \%$ for the first and third one. Only one sector, Energy, shows a rarer event by 9 percentage points. On the other hand, Tuesday effects are less likely to appear in recessions compared to expansions for all sectors except for the Financials sector. Thursday effects are more likely to appear for 4 sectors, namely Energy, Financials, Information Technology and Utilities and less likely to appear for other 4 sectors, namely Consumer Staples, Health Care, Materials and Telecommunication Services.

For positive mean returns (Table 8), the findings are the opposite. For all weekdays, it is less likely to experience significantly positive mean returns in recessions for most of the sectors. This number of sectors varies across weekdays with 5 sectors for Monday, for all 10 indices for Tuesday, 4 sectors for Wednesday, 6 sectors for Thursday and lastly 7 sectors for Friday with the exceptions of Consumer Discretionary and Materials which react significantly positively to a recession. It is important to note that for the broad S\&P500 Index it is less likely to have positive phenomena in recessions for all weekdays and the results are all significant at least at $5 \%$ level.

As for general significant day-of-the-week effects, either positive or negative (Table 91, there is a tendency not to meet them in recessions. Consequently, one can argue that the probability of finding them in expansions is greater. Specifically, 7 indices show rarer Monday effects, 9 Tuesday effects, 5 Wednesday effects, 6 Thursday effects and 7 Friday effects. The marginal effects attribute from 4 to 15 percentage points to the above considerations. However, there is not weak evidence for more frequent Friday effects in 4 sectors of Consumer Discretionary, Industrials, Information Technology and Materials with marginal effects reaching from $5 \%$ to $24 \%$.

Summing up, for most sectors and days it is more likely to have significantly negative day-of-the-week effects in recession periods compared to expansionary ones for 23 out of 55 total cases, less likely to experience positive mean returns for $37 / 55$ cases and less likely to 
Table 6 Summary results based on logit estimations (number of significant coefficients)

\begin{tabular}{|c|c|c|c|c|c|c|c|c|c|}
\hline & & Recess & ion & Unce & ainty & $\begin{array}{l}\text { Tra } \\
\text { Vol }\end{array}$ & $\begin{array}{l}\text { ding } \\
\text { ume }\end{array}$ & $\begin{array}{l}\text { Beari } \\
\text { Sentim }\end{array}$ & $\begin{array}{l}\text { sh } \\
\text { ent }\end{array}$ \\
\hline \multirow{2}{*}{ Group A } & Neg. \& Pos. & $16 / 55$ & $23 / 55$ & $6 / 55$ & $27 / 55$ & $0 / 55$ & $3 / 55$ & $10 / 55$ & $19 / 55$ \\
\hline & Total Sign. & \multicolumn{2}{|c|}{$39 / 55$} & \multicolumn{2}{|c|}{$33 / 55$} & \multicolumn{2}{|c|}{$3 / 55$} & \multicolumn{2}{|c|}{$29 / 55$} \\
\hline \multirow{2}{*}{ Group B } & Neg. \& Pos. & $37 / 55$ & $5 / 55$ & $23 / 55$ & $7 / 55$ & $3 / 55$ & $6 / 55$ & $28 / 55$ & $11 / 55$ \\
\hline & Total Sign. & \multicolumn{2}{|c|}{$42 / 55$} & \multicolumn{2}{|c|}{$30 / 55$} & \multicolumn{2}{|c|}{$9 / 55$} & \multicolumn{2}{|c|}{$39 / 55$} \\
\hline \multirow{2}{*}{ Group C } & Neg. \& Pos. & $33 / 55$ & $9 / 55$ & $25 / 55$ & $7 / 55$ & $4 / 55$ & $6 / 55$ & $16 / 55$ & $12 / 55$ \\
\hline & Total Sign. & \multicolumn{2}{|c|}{$42 / 55$} & \multicolumn{2}{|c|}{$/ 55$} & & $/ 55$ & \multicolumn{2}{|c|}{$28 / 55$} \\
\hline
\end{tabular}

Notes: Groups A, B and C consist of negative, positive and general significant day-of-the-week effects respectively. For each group, each ratio depicts the total number of cases with significant (negative and positive) coefficients out of a total of 55 marginal effects ( $55=5$ weekdays $* 11$ indices $)$ from the logit estimations (see Tables 8 to 10).

experience general significant phenomena for $33 / 55$ cases. The logit results associated with the recession index are summarized in the third column of Table 6, where fractions of cases with significant linkages to the total number of cases are presented.

There is clear evidence in the Bush and Stephens 2016 for the response of weekday seasonality to a presence of a crisis. Their research divides the sample period into three separate intervals, the pre-crisis period of 1999-2004, the period that contained the crisis 2005-2009 and the post-crisis period of 2010-2012. A substantial increase in the day-of-theweek effects (all of them being positive) was documented in the last period, which actually was believed to be impacted by the crisis, comparing to the former two. Furthermore, Lu and Gao 2016 scrutinized the effect of the global financial crisis on the Chinese stock market. During the financial crisis, more negative day-of-the-week effects, especially those related to Tuesday, were observed in contrast to the pre-crisis period of 2003-2008. The tightening of the relationship with the US financial market during the years of the crisis stood as a justification for the changing pattern, ascribing it to a spillover effect.

\subsubsection{Uncertainty}

In this subsection, we examine the effects of the uncertainty indicator. Uncertainty is measured by the Economic Policy Uncertainty (EPU) index proposed by Baker et al. 2016 . We start with the sample that consists of negative mean returns (Table 7). We observe that the probability of a presence of day-of-the-week effects is greater in uncertain times especially on Monday, Wednesday and Friday in 6,9 and 8 indices respectively. However, in all sectors and all 3 aforementioned days, the marginal effects are relatively small ranging from $0.01 \%$ to $0.04 \%$. Thursday presents the smallest effect across the 3 sectors. On the other hand, Tuesday shows a negative effect for 4 indices; Consumer Staples, Materials and Telecommunication Services together with the S\&P500 Index.

Proceeding to the positive day-of-the-week effects (Table 8), we conclude that Monday effects are more prominent in 5 sectors as uncertainty increases. The impact of a marginal increase in the uncertainty index, however, will cause a rise in the likelihood of Monday 
effects by only 0.02 to 0.05 percentage points, a rather small bump. The results for the rest of the days are converse. It is less likely for Tuesday, Wednesday and Friday effects to exist with the growth of uncertainty in 3,9 and 10 indices respectively. Thursday shows a weak association with this index.

Lastly, the significant effects (both positive and negative), reported in Table 9 , follow a similar pattern with the positive sample above. The relationship between the seasonality and the uncertainty has a positive sign for Monday but negative for the rest weekdays, except for Thursday which does not depict a strong connection.

In summary, as shown in Table 7, we conclude that it is indeed more likely to experience stronger negative daily seasonality for $27 / 55$ cases and less likely to meet a positive one for 23/55 cases as uncertainty rises. These results follow those of Penman 1987 who found a link between returns and the arrival of news. As it was noted, there was a coexistence of negative aggregate earning news on Mondays, which coincides with a high level of uncertainty in our terminology, and negative Monday mean returns. The findings for both negative and positive effects are mixed and depend on the day of the week. For example, Monday exhibits more abnormalities in an uncertain environment while Wednesday and Friday drastically less. Totally, 25/55 cases show a negative association.

\subsubsection{Trading volume}

The section uses the trading volume index as a potential driver of seasonality. We start the analysis with the sample that consists of negative mean returns (Table 7). There is little evidence to link daily abnormalities and trading volume. Only for 3 sectors, the probability of experiencing Monday phenomena is greater as the trading volume increases. These sectors are Energy, Health Care and Telecommunication Services. The corresponding marginal impacts are $11.6 \%, 11 \%$ and $5.7 \%$ respectively. It is also worth noting that the vast majority of the sectors display a positive association but not a statistically significant one at the $5 \%$ level.

Table 8 reports the results of the positive mean returns sample. We observe a stronger connection in this case. It is found that it is more likely to exhibit Wednesday effects for 5 indices, namely Consumer Staples, Financials, Industrials, Utilities and the S\&P500 Index. An interesting ascertainment is that the marginal effects for these 5 indices are considerably high. They vary from $19 \%$ to $24 \%$. On the other side, Monday appears to have a negative effect (see Health Care, Industrials and Information Technology). Only for Information Technology, Thursday effects are more likely to appear when trading volume increases.

Table 9 includes the results of the sample with all significant effects (both positive and negative). Significant results are obtained as in the previous case. The 5 significant sectors for Wednesday effects are Consumer Staples, Financials, Industrials and the Utilities sector. The corresponding magnitude of the impact is similar; average marginal effects range from $19 \%$ to $24 \%$. The probability for Monday effects is smaller. Energy (-11\%), displays less frequently Tuesday effects and Information Technology (14.5\%), shows more likely Thursday effects in periods of excess liquidity.

A summary of the above results is given in the fifth column of Table 6. Negative dayof-the-week effects are more likely to appear as liquidity rises in 3 sectors and only for Monday (3/55). This finding weakly supports the study of Fishe et al. 1993 who observed significantly lower Monday returns in a high volume bad news environment, where they defined "bad news" as the situation of experiencing negative returns on that day. Positive 
seasonality and general significant patterns behave almost identically with more frequent Wednesday effects and rarer Monday effects for 5 and 3 sectors, respectively.

\subsubsection{Bearish sentiment}

This section considers the Bearish Sentiment index as a potential driver of significant seasonalities. The first group we are looking at is that of negative mean returns. The results reported in Table 7 indicate that it is more likely to have Monday, Wednesday and Friday effects as the bearish sentiment in the market increases. This happens for 8, 3 and 5 indices respectively. The associated marginal effects range from $6.7 \%$ to $56.1 \%$. However, it is observed that the probability of experiencing daily anomalies drops in the case of Tuesday for half of the sectors examined as pessimism rises. Thursday does not show a clear pattern.

Table 8 includes the results of the positive mean returns. Here, the connection is much more explicit. It is indeed less likely to have abnormalities as the percentage of bearish investors increases for Monday, Tuesday and Friday with 7, 9 and 9 indices respectively. The drop of the likelihood of experiencing them takes values from 12.9 to 49.6 percentage points. Only Wednesday is a day with more prominent seasonality for 9 indices with the increase of pessimistic investor sentiment. The conclusion for Thursday is not clear.

Finally, Table 9 includes the results of the general day-of-the-week effects independent of their sign. Two weekdays, Monday and Wednesday appear to have more frequent anomalies in 3 and 8 indices as the number of bearish investors increases. This association is rather strong, considering the magnitude of the computed marginal effects. Their numbers range from $18.8 \%$ to $68.4 \%$. Another two weekdays, Tuesday and Friday show rarer anomalies for 8 and 4 indices respectively. High percentages were detected again, from $13 \%$ to $67.5 \%$. Thursday shows a weak connection.

A summary of the above findings appears in last column of Table 6. We find that it is more likely to meet negative day-of-the-week effects as the bearish sentiment increases for $19 / 55$ cases. As for the positive and general anomalies, the probability of experiencing them drops with the rise of pessimism in the market in 28/55 and 16/55 cases, respectively.

\section{Conclusions}

We used aggregate and sectoral S\&P500 Index data to investigate the presence of dayof-the-week effects and examine their causal determinants. Using GARCH and EGARCH models we find that the day-of-the-week effect is a wide phenomenon that is present in all sectors. Monday displays positive and statistically significant returns in all sectors, with only the exception of the Materials sector. A reverse Monday effect is therefore found in the entire sample period, which corroborates many recent studies concerning both the US and international markets 9 . Significant results for the other weekdays do exist, albeit weaker.

In the second step, we employed rolling regression techniques, thus treating seasonality as an evolving phenomenon rather than a stable one. This approach disputes the above findings for the full sample. The percentage of significant anomalies is at maximum about $1 / 5$ of the total number of regressions performed (1375 regressions for each case). The numbers calculated are slightly higher when GED distributed innovations are considered. An interesting finding is that the highest percentage of anomalies observed is on Mondays.

\footnotetext{
${ }^{9}$ See for example: Mehdian and Perry 2001, Brusa et al. 2003 and Liu and Li 2010.
} 
Monday effects are the strongest anomalies compared to the effects of the other weekdays, with Wednesday ones taking the second place. However, the evidence is weak and fails to support persistent anomalies. The weekday patterns are time-variant and do not show a constant pattern.

In the final step, we attempt to link the presence of anomalies with four potential market conditions (recessions, uncertainty, trading volume, and bearish sentiment) in a logit setup. We obtain some important results. First, we find that in recessionary, as compared to expansionary, phases, for most sectors and days, it is more likely to experience negative day-of-the-week effects, but less likely to have general significant effects (both positive and negative). Second, rising uncertainty increases the probability of negative weekday anomalies. The general significant abnormalities show a mixed structure that depends on the weekday. Third, as liquidity increases, negative day-of-the-week effects are more likely to appear in only 3 sectors. As for positive and general significant patterns - independent of their direction - more frequent Wednesday effects and rarer Monday effects are detected for 5 and 3 sectors, respectively. Fourth, it is more likely for negative day-of-the-week effects, but less likely for positive and general anomalies, to be present in a bearish environment. Our overall conclusion is that recessions and uncertainty are the most powerful determinants of the day-of-the-week effect.

In summary, our rolling-regression results provide strong evidence on the time-varying nature of seasonality appearing in the stock market. This finding has important implications for the usefulness of active trading strategies. The results imply that portfolio managers and traders would be unable to obtain profits by pursuing active strategies involving investment in sectoral indices. Our results also provide support to the efficient market hypothesis as a long-run phenomenon. 
Table 7 Marginal effects of logit (EGARCH-GED)- significantly negative (Group A)

\begin{tabular}{|c|c|c|c|c|c|}
\hline Sector & Weekday & Recession & Uncertainty & Trades & $\begin{array}{c}\text { Bearish } \\
\text { Sentiment }\end{array}$ \\
\hline \multirow{10}{*}{ S\&P500 } & \multirow{2}{*}{ Monday } & 0.0074 & $0.0001^{* *}$ & 0.0602 & $0.267^{* * *}$ \\
\hline & & $(0.721)$ & $(0.019)$ & $(0.182)$ & $(0.000)$ \\
\hline & \multirow{2}{*}{ Tuesday } & $-0.0551^{* * *}$ & $-0.0004^{* * *}$ & -0.0324 & $-0.2506^{* * *}$ \\
\hline & & $(0.000)$ & $(0.004)$ & $(0.641)$ & $(0.008)$ \\
\hline & \multirow{2}{*}{ Wednesday } & $0.2698^{* * *}$ & $0.0003^{* * *}$ & 0.064 & 0.0116 \\
\hline & & $(0.000)$ & $(0.000)$ & $(0.373)$ & $(0.875)$ \\
\hline & \multirow{2}{*}{ Thursday } & 0.0116 & 0.0000 & 0.0477 & -0.0415 \\
\hline & & $(0.518)$ & $(0.855)$ & $(0.292)$ & $(0.207)$ \\
\hline & \multirow{2}{*}{ Friday } & $0.2221^{* * *}$ & $0.0002^{* * *}$ & 0.002 & -0.053 \\
\hline & & $(0.000)$ & $(0.006)$ & $(0.963)$ & $(0.359)$ \\
\hline \multirow{10}{*}{$\begin{array}{l}\text { Consumer } \\
\text { Discretionary }\end{array}$} & \multirow{2}{*}{ Monday } & 0.0225 & $3.40 \mathrm{e}-06$ & 0.0044 & $0.2209^{* * *}$ \\
\hline & & $(0.345)$ & $(0.960)$ & $(0.923)$ & $(0.001)$ \\
\hline & \multirow{2}{*}{ Tuesday } & $-0.0658^{* * *}$ & -0.0001 & -0.0923 & 0.0932 \\
\hline & & $(0.000)$ & $(0.407)$ & $(0.201)$ & $(0.172)$ \\
\hline & \multirow{2}{*}{ Wednesday } & $0.1892^{* * *}$ & $0.0002^{* * *}$ & 0.0565 & 0.0469 \\
\hline & & $(0.000)$ & $(0.000)$ & $(0.266)$ & $(0.435)$ \\
\hline & \multirow{2}{*}{ Thursday } & 0.0114 & $9.13 \mathrm{e}-06$ & -0.0623 & $-0.129^{*}$ \\
\hline & & $(0.580)$ & $(0.925)$ & $(0.202)$ & $(0.095)$ \\
\hline & \multirow{2}{*}{ Friday } & $0.2462^{* * *}$ & $0.0002055^{* *}$ & -0.0147435 & 0.0508926 \\
\hline & & $(0.000)$ & $(0.032)$ & $(0.805)$ & $(0.477)$ \\
\hline & \multirow{2}{*}{ Monday } & -0.0041 & -0.0000 & 0.0094 & 0.018 \\
\hline & & $(0.465)$ & $(0.573)$ & $(0.248)$ & $(0.385)$ \\
\hline & \multirow{2}{*}{ Tuesday } & $-0.026^{* * *}$ & $-0.0003^{* *}$ & 0.0265 & $-0.1582^{* *}$ \\
\hline $\begin{array}{l}\text { Consumer } \\
\text { Staples }\end{array}$ & & $(0.000)$ & $(0.029)$ & $(0.435)$ & $(0.014)$ \\
\hline
\end{tabular}


Table 7 (continued)

\begin{tabular}{|c|c|c|c|c|c|}
\hline Sector & Weekday & Recession & Uncertainty & Trades & $\begin{array}{c}\text { Bearish } \\
\text { Sentiment }\end{array}$ \\
\hline & Wednesday & 0.019 & 0.0000 & -0.0234 & 0.0309 \\
\hline & & $(0.242)$ & $(0.230)$ & $(0.584)$ & $(0.411)$ \\
\hline & Thursday & $-0.0163^{*}$ & 0.0000 & -0.0438 & -0.0576 \\
\hline & & $(0.052)$ & $(0.740)$ & $(0.162)$ & $(0.196)$ \\
\hline & Friday & $0.135^{* * *}$ & $0.0002^{*}$ & 0.0207 & $0.2058^{* * *}$ \\
\hline & & $(0.000)$ & $(0.058)$ & $(0.743)$ & $(0.003)$ \\
\hline \multirow{10}{*}{ Energy } & \multirow{2}{*}{ Monday } & $-0.0914^{* * *}$ & $-0.0003^{* *}$ & $0.1161^{* *}$ & 0.0595 \\
\hline & & $(0.000)$ & $(0.024)$ & $(0.040)$ & $(0.400)$ \\
\hline & \multirow{2}{*}{ Tuesday } & $-0.0196^{*}$ & 0.0001 & 0.0386 & $-0.1034^{*}$ \\
\hline & & $(0.084)$ & $(0.338)$ & $(0.399)$ & (0.098) \\
\hline & \multirow{2}{*}{ Wednesday } & $0.0792^{* * *}$ & $0.0003^{* * *}$ & 0.0018 & -0.0191 \\
\hline & & $(0.008)$ & $(0.000)$ & $(0.980)$ & $(0.753)$ \\
\hline & \multirow{2}{*}{ Thursday } & $0.0357^{*}$ & 0.0001 & -0.0359 & 0.0044 \\
\hline & & $(0.096)$ & $(0.389)$ & $(0.436)$ & $(0.945)$ \\
\hline & \multirow{2}{*}{ Friday } & -0.0002 & -0.0001 & 0.0193 & -0.11 \\
\hline & & $(0.992)$ & $(0.218)$ & $(0.653)$ & $(0.144)$ \\
\hline \multirow{8}{*}{ Financials } & \multirow{2}{*}{ Monday } & $0.1959^{* * *}$ & $0.0003^{* * *}$ & 0.0683 & $0.5615^{* * *}$ \\
\hline & & $(0.000)$ & $(0.000)$ & $(0.147)$ & $(0.000)$ \\
\hline & \multirow{2}{*}{ Tuesday } & 0.0004 & -0.0000 & 0.0007 & 0.0495 \\
\hline & & $(0.982)$ & $(0.790)$ & $(0.986)$ & $(0.322)$ \\
\hline & \multirow{2}{*}{ Wednesday } & $0.3324^{* * *}$ & $0.0003^{* * *}$ & -0.0931 & $0.2549 * * *$ \\
\hline & & $(0.000)$ & $(0.000)$ & $(0.295)$ & $(0.000)$ \\
\hline & \multirow{2}{*}{ Thursday } & $0.1512^{* * *}$ & 0.0000 & 0.1092 & $0.2769^{* * *}$ \\
\hline & & $(0.000)$ & $(0.822)$ & $(0.184)$ & $(0.000)$ \\
\hline
\end{tabular}


Table 7 (continued)

\begin{tabular}{|c|c|c|c|c|c|}
\hline Sector & Weekday & Recession & Uncertainty & Trades & $\begin{array}{c}\text { Bearish } \\
\text { Sentiment }\end{array}$ \\
\hline & Friday & $0.1456^{* * *}$ & $0.0002^{* *}$ & 0.0581 & 0.0108 \\
\hline & & $(0.000)$ & $(0.019)$ & $(0.314)$ & $(0.878)$ \\
\hline \multirow{10}{*}{ Health Care } & \multirow{2}{*}{ Monday } & $0.0524^{* *}$ & $0.0001^{* *}$ & $0.1096^{* * *}$ & $0.2226^{* * *}$ \\
\hline & & $(0.025)$ & $(0.020)$ & $(0.000)$ & $(0.000)$ \\
\hline & \multirow{2}{*}{ Tuesday } & $-0.0495^{* * *}$ & $0.0001^{* *}$ & -0.0062 & $0.1517^{* *}$ \\
\hline & & $(0.000)$ & $(0.015)$ & $(0.911)$ & $(0.020)$ \\
\hline & \multirow{2}{*}{ Wednesday } & $0.051^{* *}$ & $0.0001^{* * *}$ & 0.045 & $0.0924^{* *}$ \\
\hline & & $(0.016)$ & $(0.000)$ & $(0.197)$ & $(0.015)$ \\
\hline & \multirow{2}{*}{ Thursday } & $-0.026^{* * *}$ & $0.0001^{*}$ & -0.0089 & 0.0264 \\
\hline & & $(0.003)$ & $(0.072)$ & $(0.848)$ & $(0.422)$ \\
\hline & \multirow{2}{*}{ Friday } & 0.0128 & 0.0000 & -0.013 & $0.067^{* *}$ \\
\hline & & $(0.384)$ & $(0.468)$ & $(0.430)$ & $(0.040)$ \\
\hline \multirow{12}{*}{ Industrials } & \multirow{2}{*}{ Monday } & -0.0168 & $0.0002^{* *}$ & 0.0541 & $0.3597^{* * *}$ \\
\hline & & $(0.398)$ & $(0.017)$ & $(0.312)$ & $(0.000)$ \\
\hline & \multirow{2}{*}{ Tuesday } & $-0.0179^{* *}$ & -0.0001 & -0.0481 & $0.085^{* * *}$ \\
\hline & & $(0.034)$ & $(0.257)$ & $(0.341)$ & $(0.005)$ \\
\hline & \multirow{2}{*}{ Wednesday } & $0.3898^{* * *}$ & $0.0004^{* * *}$ & 0.0102 & $0.263^{* * *}$ \\
\hline & & $(0.000)$ & $(0.000)$ & $(0.914)$ & $(0.000)$ \\
\hline & \multirow{2}{*}{ Thursday } & -0.0058 & 0.0000 & 0.0218 & -0.0182 \\
\hline & & $(0.464)$ & $(0.322)$ & $(0.498)$ & $(0.337)$ \\
\hline & \multirow{2}{*}{ Friday } & $0.284^{* * *}$ & $0.0004^{* * *}$ & 0.0254 & $0.1875^{* * *}$ \\
\hline & & $(0.000)$ & $(0.000)$ & $(0.617)$ & $(0.010)$ \\
\hline & \multirow{2}{*}{ Monday } & $0.1997^{* * *}$ & $0.0003^{* * *}$ & 0.0389 & $0.3564^{* * *}$ \\
\hline & & $(0.000)$ & $(0.000)$ & $(0.481)$ & $(0.000)$ \\
\hline
\end{tabular}

Information 
Table 7 (continued)

\begin{tabular}{|c|c|c|c|c|c|}
\hline Sector & Weekday & Recession & Uncertainty & Trades & $\begin{array}{c}\text { Bearish } \\
\text { Sentiment }\end{array}$ \\
\hline & \multirow{2}{*}{ Tuesday } & $-0.0365^{* * *}$ & -0.0001 & -0.0539 & $-0.1415^{* *}$ \\
\hline & & $(0.000)$ & $(0.322)$ & $(0.245)$ & $(0.017)$ \\
\hline & \multirow{2}{*}{ Wednesday } & $0.1942^{* * *}$ & $0.0001^{* * *}$ & -0.0354 & 0.0472 \\
\hline & & $(0.000)$ & $(0.000)$ & $(0.442)$ & $(0.279)$ \\
\hline & \multirow{2}{*}{ Thursday } & $0.0604^{* *}$ & 0.0000 & 0.0988 & 0.0546 \\
\hline & & $(0.017)$ & $(0.620)$ & $(0.123)$ & $(0.353)$ \\
\hline & \multirow{2}{*}{ Friday } & $0.2751^{* * *}$ & $0.0003^{* * *}$ & 0.0522 & 0.1321 \\
\hline & & $(0.000)$ & $(0.002)$ & $(0.337)$ & $(0.105)$ \\
\hline \multirow{10}{*}{ Materials } & \multirow{2}{*}{ Monday } & 0.0209 & $0.0001^{* *}$ & 0.0374 & $0.2790^{* * *}$ \\
\hline & & $(0.381)$ & $(0.024)$ & $(0.482)$ & $(0.000)$ \\
\hline & \multirow{2}{*}{ Tuesday } & $-0.0481^{* * *}$ & $-0.0005^{* * *}$ & 0.0879 & $-0.2409^{* * *}$ \\
\hline & & $(0.003)$ & $(0.005)$ & $(0.163)$ & $(0.002)$ \\
\hline & \multirow{2}{*}{ Wednesday } & $-0.0228^{* *}$ & 0.0000 & -0.0076 & $-0.2461^{* * *}$ \\
\hline & & $(0.046)$ & $(0.661)$ & $(0.922)$ & $(0.000)$ \\
\hline & \multirow{2}{*}{ Thursday } & $-0.0567 * * *$ & $0.0002^{* *}$ & -0.0087 & -0.0715 \\
\hline & & $(0.000)$ & $(0.046)$ & $(0.880)$ & $(0.215)$ \\
\hline & \multirow{2}{*}{ Friday } & $0.1891^{* * *}$ & 0.0002 & 0.0237 & $-0.0952^{*}$ \\
\hline & & $(0.000)$ & $(0.001)$ & $(0.491)$ & $(0.068)$ \\
\hline \multirow{6}{*}{$\begin{array}{l}\text { Telecom } \\
\text { Services }\end{array}$} & \multirow{2}{*}{ Monday } & 0.0182 & 0.0000 & $0.0571^{* *}$ & $0.1428^{* * *}$ \\
\hline & & $(0.263)$ & $(0.252)$ & $(0.019)$ & $(0.000)$ \\
\hline & \multirow{2}{*}{ Tuesday } & $-0.0487^{* * *}$ & $-0.0002^{* *}$ & 0.0179 & -0.1076 \\
\hline & & $(0.000)$ & $(0.047)$ & $(0.735)$ & $(0.199)$ \\
\hline & \multirow{2}{*}{ Wednesday } & $0.3660^{* * *}$ & $0.0004^{* * *}$ & -0.0822 & 0.0333 \\
\hline & & $(0.000)$ & $(0.000)$ & $(0.455)$ & $(0.713)$ \\
\hline
\end{tabular}


Table 7 (continued)

\begin{tabular}{|c|c|c|c|c|c|}
\hline Sector & Weekday & Recession & Uncertainty & Trades & $\begin{array}{c}\text { Bearish } \\
\text { Sentiment }\end{array}$ \\
\hline & \multirow{2}{*}{ Thursday } & $-0.0348^{* * *}$ & $-0.0003^{* *}$ & -0.0062 & $-0.0929^{*}$ \\
\hline & & $(0.000)$ & $(0.015)$ & $(0.898)$ & $(0.061)$ \\
\hline & \multirow{2}{*}{ Friday } & 0.0232 & $0.0002^{* * *}$ & -0.0487 & $0.1534^{* * *}$ \\
\hline & & $(0.259)$ & $(0.001)$ & $(0.160)$ & $(0.001)$ \\
\hline \multirow{10}{*}{ Utilities } & \multirow{2}{*}{ Monday } & 0.0015 & $4.34 \mathrm{e}-07$ & -0.0308 & $-0.0675^{*}$ \\
\hline & & $(0.838)$ & $(0.991)$ & $(0.142)$ & $(0.062)$ \\
\hline & \multirow{2}{*}{ Tuesday } & $-0.03^{* * *}$ & -0.0000 & -0.0298 & -0.0229 \\
\hline & & $(0.000)$ & $(0.583)$ & $(0.651)$ & $(0.568)$ \\
\hline & \multirow{2}{*}{ Wednesday } & 0.0008 & $0.0003^{* * *}$ & -0.0307 & -0.0375 \\
\hline & & $(0.970)$ & $(0.000)$ & $(0.691)$ & $(0.529)$ \\
\hline & \multirow{2}{*}{ Thursday } & $0.1856^{* * *}$ & $0.0003^{* * *}$ & -0.0505 & 0.1168 \\
\hline & & $(0.000)$ & $(0.002)$ & $(0.525)$ & $(0.129)$ \\
\hline & \multirow{2}{*}{ Friday } & $0.0724^{* * *}$ & $0.0001^{* * *}$ & -0.0111 & $0.0931^{* * *}$ \\
\hline & & $(0.002)$ & $(0.002)$ & $(0.723)$ & $(0.002)$ \\
\hline
\end{tabular}

Notes: ${ }^{*}, * *$ and $* * *$ denote statistical significance at the $10 \%, 5 \%$ and $1 \%$ significance levels respectively. In each case, the marginal effect is presented followed by the associated $p$-value in parentheses.

Table 8 Marginal effects of logit (EGARCH-GED) - significantly positive (Group B)

\begin{tabular}{lccccc}
\hline \multirow{2}{*}{ Sector } & Weekday & Recession & Uncertainty & Trades & $\begin{array}{c}\text { Bearish } \\
\text { Sentiment }\end{array}$ \\
\hline \multirow{2}{*}{ Monday } & $-0.1284^{* * *}$ & 0.0002 & -0.123 & -0.1551 \\
\cline { 3 - 6 } & & $(0.000)$ & $(0.149)$ & $(0.182)$ & $(0.124)$ \\
\cline { 2 - 6 } & Tuesday & $-0.0866^{* * *}$ & $-0.0003^{* *}$ & -0.0114 & $-0.2173^{* * *}$ \\
\cline { 2 - 6 } & & $(0.000)$ & $(0.037)$ & $(0.904)$ & $(0.008)$ \\
\cline { 2 - 6 } & Wednesday & $-0.0475^{* *}$ & $-0.0009^{* * *}$ & $0.1863^{* *}$ & $0.2571^{* * *}$
\end{tabular}


Table 8 (continued)

\begin{tabular}{|c|c|c|c|c|c|}
\hline Sector & Weekday & Recession & Uncertainty & Trades & $\begin{array}{c}\text { Bearish } \\
\text { Sentiment }\end{array}$ \\
\hline & & $(0.020)$ & $(0.000)$ & $(0.049)$ & $(0.001)$ \\
\hline & Thursday & $-0.0575^{* * *}$ & $-6.05 \mathrm{e}-06$ & 0.0134 & 0.0156 \\
\hline & & $(0.000)$ & $(0.944)$ & $(0.865)$ & $(0.792)$ \\
\hline & Fridav & $-0.0948^{* * *}$ & $-0.0003^{*}$ & 0.0738 & -0.08 \\
\hline & & $(0.000)$ & $(0.072)$ & $(0.353)$ & $(0.354)$ \\
\hline \multirow{10}{*}{$\begin{array}{l}\text { Consumer } \\
\text { Discretionary }\end{array}$} & \multirow{2}{*}{ Monday } & $-0.1516^{* * *}$ & $0.0005^{* * *}$ & -0.0268 & $-0.3292^{* * *}$ \\
\hline & & $(0.000)$ & $(0.001)$ & $(0.767)$ & $(0.001)$ \\
\hline & \multirow{2}{*}{ Tuesday } & $-0.0777 * * *$ & -0.0002 & 0.0784 & $-0.4802^{* * *}$ \\
\hline & & $(0.000)$ & $(0.154)$ & $(0.331)$ & $(0.000)$ \\
\hline & \multirow{2}{*}{ Wednesday } & $-0.0641^{* * *}$ & $-0.0002^{* *}$ & 0.0999 & $0.2393^{* * *}$ \\
\hline & & $(0.000)$ & $(0.047)$ & $(0.212)$ & $(0.000)$ \\
\hline & \multirow{2}{*}{ Thursday } & $-0.0723^{* * *}$ & 0.0001 & 0.107 & -0.0052 \\
\hline & & $(0.000)$ & $(0.237)$ & $(0.160)$ & $(0.937)$ \\
\hline & \multirow{2}{*}{ Friday } & $0.0566^{* * *}$ & $-0.0002^{* *}$ & -0.0213 & $-0.3074^{* * *}$ \\
\hline & & $(0.000)$ & $(0.024)$ & $(0.654)$ & $(0.000)$ \\
\hline \multirow{9}{*}{$\begin{array}{l}\text { Consumer } \\
\text { Staples }\end{array}$} & \multirow{2}{*}{ Monday } & $-0.1312^{* * *}$ & $0.0002^{*}$ & -0.095 & -0.1445 \\
\hline & & $(0.000)$ & $(0.074)$ & $(0.295)$ & $(0.109)$ \\
\hline & \multirow{2}{*}{ Tuesday } & $0.1972^{* * *}$ & $0.0002^{* *}$ & -0.0464 & 0.096 \\
\hline & & $(0.000)$ & $(0.048)$ & $(0.610)$ & $(0.320)$ \\
\hline & \multirow{2}{*}{ Wednesday } & $0.0449^{*}$ & $-0.0004^{* *}$ & $0.1954^{* *}$ & $0.4703^{* * *}$ \\
\hline & & $(0.089)$ & $(0.017)$ & $(0.014)$ & $(0.000)$ \\
\hline & \multirow{2}{*}{ Thursday } & $-0.0842^{* * *}$ & 0.0001 & 0.0455 & $0.1052^{*}$ \\
\hline & & $(0.000)$ & $(0.177)$ & $(0.536)$ & $(0.085)$ \\
\hline & Friday & $-0.0979^{* * *}$ & $-0.0006^{* * *}$ & 0.0346 & $-0.3902^{* * *}$ \\
\hline
\end{tabular}


Table 8 (continued)

\begin{tabular}{|c|c|c|c|c|c|}
\hline Sector & Weekday & Recession & Uncertainty & Trades & $\begin{array}{c}\text { Bearish } \\
\text { Sentiment }\end{array}$ \\
\hline & & $(0.000)$ & $(0.001)$ & $(0.603)$ & $(0.000)$ \\
\hline \multirow{10}{*}{ Energy } & \multirow{2}{*}{ Monday } & -0.1218 & -0.0000 & -0.026 & $-0.3701^{* * *}$ \\
\hline & & $(0.000)$ & $(0.927)$ & $(0.765)$ & $(0.000)$ \\
\hline & \multirow{2}{*}{ Tuesday } & $-0.0373^{* * *}$ & $-6.40 \mathrm{e}-06$ & -0.1095 & $-0.2107^{* * *}$ \\
\hline & & $(0.000)$ & $(0.924)$ & $(0.038)$ & $(0.001)$ \\
\hline & \multirow{2}{*}{ Wednesday } & 0.0304 & -0.0004 & 0.063 & $-0.1707^{*}$ \\
\hline & & $(0.236)$ & $(0.028)$ & $(0.402)$ & $(0.077)$ \\
\hline & \multirow{2}{*}{ Thursday } & $-0.0203^{* * *}$ & -0.0000 & -0.0487 & $-0.0679^{*}$ \\
\hline & & $(0.002)$ & $(0.816)$ & $(0.131)$ & $(0.065)$ \\
\hline & \multirow{2}{*}{ Friday } & -0.0712 & -0.0003 & -0.0499 & $-0.4963^{* * *}$ \\
\hline & & $(0.000)$ & $(0.083)$ & $(0.345)$ & $(0.000)$ \\
\hline \multirow{13}{*}{ Financials } & \multirow{2}{*}{ Monday } & 0.0087 & 0.0001 & -0.0512 & $-0.3123^{* * *}$ \\
\hline & & $(0.786)$ & $(0.519)$ & $(0.507)$ & $(0.001)$ \\
\hline & \multirow{2}{*}{ Tuesday } & $-0.0359^{* *}$ & 0.0001 & 0.022 & $-0.2188^{* *}$ \\
\hline & & $(0.023)$ & $(0.517)$ & $(0.788)$ & $(0.016)$ \\
\hline & \multirow{2}{*}{ Wednesday } & 0.0021 & $-0.0004^{* * *}$ & $0.2323^{* *}$ & $0.3225^{* * *}$ \\
\hline & & $(0.936)$ & $(0.005)$ & $(0.017)$ & $(0.000)$ \\
\hline & \multirow{2}{*}{ Thursday } & $-0.0219^{* * *}$ & $0.0001^{*}$ & 0.0395 & 0.0021 \\
\hline & & $(0.001)$ & $(0.072)$ & $(0.451)$ & $(0.948)$ \\
\hline & \multirow{2}{*}{ Friday } & $-0.0349 * *$ & $-0.0006^{* * *}$ & 0.0071 & -0.1152 \\
\hline & & $(0.028)$ & $(0.001)$ & $(0.906)$ & $(0.126)$ \\
\hline & \multirow{2}{*}{ Monday } & -0.0052 & $0.0005^{* * *}$ & $-0.2028^{* *}$ & $-0.3578^{* * *}$ \\
\hline & & $(0.875)$ & $(0.001)$ & $(0.039)$ & $(0.000)$ \\
\hline & Tuesday & $-0.1126^{* * *}$ & -0.0000 & 0.0563 & $-0.4471^{* * *}$ \\
\hline
\end{tabular}

Health Care 
Table 8 (continued)

\begin{tabular}{|c|c|c|c|c|c|}
\hline Sector & Weekday & Recession & Uncertainty & Trades & $\begin{array}{c}\text { Bearish } \\
\text { Sentiment }\end{array}$ \\
\hline & & $(0.000)$ & $(0.835)$ & $(0.527))$ & $(0.000)$ \\
\hline & Wednesdav & $-0.0692^{* * *}$ & $-0.001^{* * *}$ & 0.0948 & $0.1699^{* *}$ \\
\hline & & $(0.000)$ & $(0.000)$ & $(0.316)$ & $(0.035)$ \\
\hline & Thursdav & -0.0289 & $-0.0004^{* * *}$ & 0.0062 & -0.0113 \\
\hline & & $(0.150)$ & $(0.005)$ & $(0.932)$ & $(0.870)$ \\
\hline & Friday & $-0.5658^{* * *}$ & $-0.0003^{* *}$ & 0.025 & $-0.2731^{* * *}$ \\
\hline & & $(0.000)$ & $(0.024)$ & $(0.525)$ & $(0.000)$ \\
\hline \multirow{10}{*}{ Industrials } & \multirow{2}{*}{ Monday } & $-0.0431^{*}$ & $0.0002^{*}$ & $-0.175^{* *}$ & -0.0091 \\
\hline & & $(0.093)$ & $(0.092)$ & $(0.043)$ & $(0.917)$ \\
\hline & \multirow{2}{*}{ Tuesday } & $-0.0575 * * *$ & $-0.0003^{* *}$ & 0.0116 & $-0.2447^{* * *}$ \\
\hline & & $(0.000)$ & $(0.031)$ & $(0.865)$ & $(0.000)$ \\
\hline & \multirow{2}{*}{ Wednesday } & 0.0149 & $-0.0003^{* *}$ & $0.1867^{* *}$ & $0.413^{* * *}$ \\
\hline & & $(0.590)$ & $(0.028)$ & $(0.038)$ & $(0.000)$ \\
\hline & \multirow{2}{*}{ Thursday } & $-0.0437^{* * *}$ & -0.0000 & 0.0198 & $-0.1687^{* * *}$ \\
\hline & & $(0.000)$ & $(0.758)$ & $(0.731)$ & $(0.000)$ \\
\hline & \multirow{2}{*}{ Friday } & $-0.0816^{* * *}$ & $-0.0005^{* * *}$ & 0.0267 & $-0.2321^{* * *}$ \\
\hline & & $(0.000)$ & $(0.000)$ & $(0.570)$ & $(0.001)$ \\
\hline \multirow{7}{*}{$\begin{array}{l}\text { Information } \\
\text { Technology }\end{array}$} & \multirow{2}{*}{ Monday } & -0.0152 & -0.0000 & $-0.1641^{*}$ & $-0.285^{* * *}$ \\
\hline & & $(0.605)$ & $(0.897)$ & $(0.083)$ & $(0.008)$ \\
\hline & \multirow{2}{*}{ Tuesday } & $-0.0383^{* * *}$ & $-0.0005^{* * *}$ & -0.0546 & $-0.2415^{* * *}$ \\
\hline & & $(0.006)$ & $(0.002)$ & $(0.550)$ & $(0.002)$ \\
\hline & \multirow{2}{*}{ Wednesday } & $-0.1293^{* * *}$ & $-0.0003^{*}$ & 0.0942 & $0.3717^{* * *}$ \\
\hline & & $(0.000)$ & $(0.092)$ & $(0.454)$ & $(0.000)$ \\
\hline & Thursday & -0.0211 & 0.0002 & $0.1448^{*}$ & -0.0442 \\
\hline
\end{tabular}


Table 8 (continued)

\begin{tabular}{|c|c|c|c|c|c|}
\hline Sector & Weekday & Recession & Uncertainty & Trades & $\begin{array}{c}\text { Bearish } \\
\text { Sentiment }\end{array}$ \\
\hline & & $(0.368)$ & $(0.122)$ & $(0.064)$ & $(0.563)$ \\
\hline & Friday & $-0.0348^{* * *}$ & $-0.0008^{* * *}$ & -0.0053 & $-0.316^{* * *}$ \\
\hline & & $(0.000)$ & $(0.000)$ & $(0.889)$ & $(0.000)$ \\
\hline \multirow{10}{*}{ Materials } & \multirow{2}{*}{ Monday } & $-0.0971^{* * *}$ & -0.0000 & -0.0937 & $-0.1726^{* *}$ \\
\hline & & $(0.000)$ & $(0.893)$ & $(0.169)$ & $(0.029)$ \\
\hline & \multirow{2}{*}{ Tuesday } & $-0.0575^{* * *}$ & -0.0002 & 0.0685 & $-0.4635^{* * *}$ \\
\hline & & $(0.000)$ & $(0.133)$ & $(0.359)$ & $(0.000)$ \\
\hline & \multirow{2}{*}{ Wednesday } & 0.0179 & $-0.0002^{*}$ & 0.033 & $0.1943^{* * *}$ \\
\hline & & $(0.383)$ & $(0.056)$ & $(0.576)$ & $(0.000)$ \\
\hline & \multirow{2}{*}{ Thursday } & $-0.0373 * * *$ & -0.0001 & -0.08 & 0.0571 \\
\hline & & $(0.000)$ & $(0.136)$ & $(0.211)$ & $(0.178)$ \\
\hline & \multirow{2}{*}{ Friday } & $0.0514^{* *}$ & $-0.0002^{* *}$ & 0.0153 & $0.1289^{* *}$ \\
\hline & & $(0.029)$ & $(0.027)$ & $(0.730)$ & $(0.014)$ \\
\hline \multirow{10}{*}{$\begin{array}{l}\text { Telecom } \\
\text { Services }\end{array}$} & \multirow{2}{*}{ Monday } & $-0.1658^{* * *}$ & $0.0004^{* * *}$ & 0.0158 & $-0.3558^{* * *}$ \\
\hline & & $(0.000)$ & $(0.003)$ & $(0.847)$ & $(0.000)$ \\
\hline & \multirow{2}{*}{ Tuesday } & $-0.0769^{* * *}$ & -0.0000 & 0.0833 & $-0.3163^{* * *}$ \\
\hline & & $(0.000)$ & $(0.855)$ & $(0.308)$ & $(0.000)$ \\
\hline & \multirow{2}{*}{ Wednesday } & $-0.0665^{* * *}$ & 0.0001 & 0.0718 & $-0.2521^{* * *}$ \\
\hline & & $(0.000)$ & $(0.315)$ & $(0.361)$ & $(0.002)$ \\
\hline & \multirow{2}{*}{ Thursday } & $-0.0439^{* * *}$ & -0.0001 & 0.0206 & 0.0598 \\
\hline & & $(0.000)$ & $(0.392)$ & $(0.770)$ & $(0.208)$ \\
\hline & \multirow{2}{*}{ Friday } & $-0.0663^{* * *}$ & $-0.0007^{* * *}$ & 0.0265 & $-0.2989^{* * *}$ \\
\hline & & $(0.000)$ & $(0.000)$ & $(0.586)$ & $(0.000)$ \\
\hline & Monday & $0.0724^{*}$ & 0.0001 & -0.075 & 0.132 \\
\hline
\end{tabular}


Table 8 (continued)

\begin{tabular}{lccccc}
\hline Sector & Weekday & Recession & Uncertainty & Trades & $\begin{array}{c}\text { Bearish } \\
\text { Sentiment }\end{array}$ \\
\hline \multirow{2}{*}{ Tuesday } & $(0.054)$ & $(0.523)$ & $(0.408)$ & $(0.214)$ \\
\cline { 2 - 5 } & -0.0117 & -0.0002 & -0.0312 & -0.0179 \\
\hline \multirow{2}{*}{ Wednesday } & -0.0161 & $-0.0002^{*}$ & $0.2361^{* * *}$ & $0.3846^{* * *}$ \\
\cline { 2 - 5 } & $(0.447)$ & $(0.068)$ & $(0.003)$ & $(0.000)$ \\
\hline \multirow{2}{*}{ Thursday } & $-0.0187^{* * *}$ & $3.74 \mathrm{e}-06$ & -0.0019 & -0.0175 \\
\cline { 2 - 5 } & $(0.004)$ & $(0.923)$ & $(0.954)$ & $(0.454)$ \\
\hline \multirow{2}{*}{ Friday } & $-0.1155^{* * *}$ & $-0.0009^{* * *}$ & 0.0899 & $-0.3871^{* * *}$ \\
\cline { 2 - 5 } & $(0.000)$ & $(0.000)$ & $(0.141)$ & $(0.000)$ \\
\hline
\end{tabular}

Notes: ${ }^{*}, * *$ and $* * *$ denote statistical significance at the $10 \%, 5 \%$ and $1 \%$ significance levels respectively. In each case, the marginal effect is presented followed by the associated $p$-value in parentheses.

Table 9 Marginal effects of logit (EGARCH-GED) - all significant (Group C)

\begin{tabular}{lccccc}
\hline \multirow{2}{*}{ Sector } & Weekday & Recession & Uncertainty & Trades & $\begin{array}{c}\text { Bearish } \\
\text { Sentiment }\end{array}$ \\
\hline \multirow{2}{*}{ Monday } & $-0.1284^{* * *}$ & 0.0002 & -0.123 & 0.1526 \\
\cline { 3 - 6 } & Tuesday & $-0.1417^{* * *}$ & $-0.0003^{* *}$ & -0.0114 & $-0.4612^{* * *}$ \\
\cline { 2 - 6 } & Wednesday & $-0.0475^{* *}$ & $-0.0009^{* * *}$ & $0.1863^{* *}$ & $0.2757^{* * *}$ \\
\cline { 2 - 6 } & & $(0.000)$ & $(0.037)$ & $(0.904)$ & $(0.000)$ \\
\cline { 2 - 6 } & Thursday & $-0.0575^{* * *}$ & $-6.05 \mathrm{e}-06$ & 0.0134 & -0.0245 \\
\cline { 2 - 5 } & & $(0.000)$ & $(0.944)$ & $(0.865)$ & $(0.718)$ \\
\cline { 2 - 5 } & Friday & $-0.0948^{* * *}$ & $-0.0003^{*}$ & 0.0738 & -0.1324 \\
\cline { 2 - 5 } & $(0.000)$ & $(0.072)$ & $(0.353)$ & $(0.185)$ \\
\hline
\end{tabular}


Table 9 (continued)

\begin{tabular}{|c|c|c|c|c|c|}
\hline Sector & Weekday & Recession & Uncertainty & Trades & $\begin{array}{c}\text { Bearish } \\
\text { Sentiment }\end{array}$ \\
\hline \multirow{10}{*}{$\begin{array}{l}\text { Consumer } \\
\text { Discretionary }\end{array}$} & \multirow{2}{*}{ Monday } & $-0.1516^{* * *}$ & $0.0005^{* * *}$ & -0.0268 & -0.0696 \\
\hline & & $(0.000)$ & $(0.001)$ & $(0.767)$ & $(0.546)$ \\
\hline & \multirow{2}{*}{ Tuesday } & $-0.1434^{* * *}$ & -0.0002 & 0.0784 & $-0.3244^{* * *}$ \\
\hline & & $(0.000)$ & $(0.154)$ & $(0.331)$ & $(0.002)$ \\
\hline & \multirow{2}{*}{ Wednesday } & $-0.0641 * * *$ & $-0.0002^{* *}$ & 0.0999 & $0.2899^{* * *}$ \\
\hline & & $(0.000)$ & $(0.047)$ & $(0.212)$ & $(0.001)$ \\
\hline & \multirow{2}{*}{ Thursday } & $-0.0723^{* * *}$ & 0.0001 & 0.107 & -0.1279 \\
\hline & & $(0.000)$ & $(0.237)$ & $(0.160)$ & $(0.177)$ \\
\hline & \multirow{2}{*}{ Friday } & $0.1575^{* * *}$ & $-0.0002^{* *}$ & -0.0213 & $-0.2209 * *$ \\
\hline & & $(0.000)$ & $(0.024)$ & $(0.654)$ & $(0.022)$ \\
\hline \multirow{10}{*}{$\begin{array}{l}\text { Consumer } \\
\text { Staples }\end{array}$} & \multirow{2}{*}{ Monday } & $-0.1312^{* * *}$ & $0.0002^{*}$ & -0.095 & -0.1238 \\
\hline & & $(0.000)$ & $(0.074)$ & $(0.295)$ & $(0.178)$ \\
\hline & \multirow{2}{*}{ Tuesday } & $0.1972^{* * *}$ & $0.0002^{* *}$ & -0.0464 & -0.036 \\
\hline & & $(0.000)$ & $(0.048)$ & $(0.610)$ & $(0.744)$ \\
\hline & \multirow{2}{*}{ Wednesday } & $0.0449^{*}$ & $-0.0004^{* *}$ & $0.1954^{* *}$ & $0.5141^{* * *}$ \\
\hline & & $(0.089)$ & $(0.017)$ & $(0.014)$ & $(0.000)$ \\
\hline & \multirow{2}{*}{ Thursday } & $-0.0842^{* * *}$ & 0.0001 & 0.0455 & 0.0546 \\
\hline & & $(0.000)$ & $(0.177)$ & $(0.536)$ & $(0.452)$ \\
\hline & \multirow{2}{*}{ Friday } & $-0.0979 * * *$ & $-0.0006^{* * *}$ & 0.0346 & -0.1394 \\
\hline & & $(0.000)$ & $(0.001)$ & $(0.603)$ & $(0.211)$ \\
\hline & \multirow{2}{*}{ Monday } & $-0.1218^{* * *}$ & -0.0000 & -0.026 & $-0.2949^{* * *}$ \\
\hline & & $(0.000)$ & $(0.927)$ & $(0.765)$ & $(0.008)$ \\
\hline & \multirow{2}{*}{ Tuesday } & $-0.0569^{* * *}$ & $-6.40 \mathrm{e}-06$ & $-0.1095^{* *}$ & $-0.3096^{* * *}$ \\
\hline Energy & & $(0.000)$ & $(0.924)$ & $(0.038)$ & $(0.000)$ \\
\hline
\end{tabular}


Table 9 (continued)

\begin{tabular}{|c|c|c|c|c|c|}
\hline Sector & Weekday & Recession & Uncertainty & Trades & $\begin{array}{c}\text { Bearish } \\
\text { Sentiment }\end{array}$ \\
\hline & Wednesdav & 0.0304 & $-0.0004^{* *}$ & 0.063 & $-0.1844^{*}$ \\
\hline & & $(0.236)$ & $(0.028)$ & $(0.402)$ & $(0.081)$ \\
\hline & Thursday & 0.0149 & -0.0000 & -0.0487 & -0.0593 \\
\hline & & $(0.502)$ & $(0.816)$ & $(0.131)$ & $(0.427)$ \\
\hline & Friday & $-0.0712^{* * *}$ & $-0.0003^{*}$ & -0.0499 & $-0.5908^{* * *}$ \\
\hline & & $(0.000)$ & $(0.083)$ & $(0.345)$ & $(0.000)$ \\
\hline \multirow{10}{*}{ Financials } & \multirow{2}{*}{ Monday } & 0.0087 & 0.0001 & -0.0512 & $0.3575^{* * *}$ \\
\hline & & $(0.786)$ & $(0.519)$ & $(0.507)$ & $(0.002)$ \\
\hline & \multirow{2}{*}{ Tuesday } & $-0.0359^{* *}$ & 0.0001 & 0.022 & -0.1533 \\
\hline & & $(0.023)$ & $(0.517)$ & $(0.788)$ & $(0.117)$ \\
\hline & \multirow{2}{*}{ Wednesday } & 0.0021 & $-0.0004^{* * *}$ & $0.2323^{* *}$ & $0.5858^{* * *}$ \\
\hline & & $(0.936)$ & $(0.005)$ & $(0.017)$ & $(0.000)$ \\
\hline & \multirow{2}{*}{ Thursday } & $0.1279^{* * *}$ & $0.0001^{*}$ & 0.0395 & $0.2853^{* * *}$ \\
\hline & & $(0.000)$ & $(0.072)$ & $(0.451)$ & $(0.000)$ \\
\hline & \multirow{2}{*}{ Friday } & $-0.0349^{* *}$ & $-0.0006^{* * *}$ & 0.0071 & -0.1006 \\
\hline & & $(0.028)$ & $(0.001)$ & $(0.906)$ & $(0.310)$ \\
\hline \multirow{8}{*}{ Health Care } & \multirow{2}{*}{ Monday } & -0.0052 & $0.0005^{* * *}$ & $-0.2028^{* *}$ & -0.0731 \\
\hline & & $(0.875)$ & $(0.001)$ & $(0.039)$ & $(0.509)$ \\
\hline & \multirow[t]{2}{*}{ Tuesday } & $-0.1126^{* * *}$ & -0.0000 & 0.0563 & $-0.2509^{* *}$ \\
\hline & & $(0.000)$ & $(0.835)$ & $(0.527)$ & $(0.022)$ \\
\hline & \multirow{2}{*}{ Wednesday } & $-0.0692^{* * *}$ & $-0.001^{* * *}$ & 0.0948 & $0.2676^{* * *}$ \\
\hline & & $(0.000)$ & $(0.000)$ & $(0.316)$ & $(0.002)$ \\
\hline & \multirow{2}{*}{ Thursday } & -0.0289 & $-0.0004^{* * *}$ & 0.0062 & 0.0158 \\
\hline & & $(0.150)$ & $(0.005)$ & $(0.932)$ & $(0.834)$ \\
\hline
\end{tabular}


Table 9 (continued)

\begin{tabular}{|c|c|c|c|c|c|}
\hline Sector & Weekday & Recession & Uncertainty & Trades & $\begin{array}{c}\text { Bearish } \\
\text { Sentiment }\end{array}$ \\
\hline & Friday & $-0.044^{* * *}$ & $-0.0003^{* *}$ & 0.025 & $-0.1746^{* *}$ \\
\hline & & (0.009) & $(0.024)$ & $(0.525)$ & $(0.018)$ \\
\hline \multirow{10}{*}{ Industrials } & \multirow{2}{*}{ Monday } & $-0.0431^{*}$ & $0.0002^{*}$ & $-0.175^{* *}$ & $0.388^{* * *}$ \\
\hline & & (0.093) & $(0.092)$ & $(0.043)$ & $(0.000)$ \\
\hline & \multirow{2}{*}{ Tuesday } & $-0.0575^{* * *}$ & $-0.0003^{* *}$ & 0.0116 & $-0.13^{*}$ \\
\hline & & $(0.000)$ & $(0.031)$ & $(0.865)$ & $(0.058)$ \\
\hline & \multirow{2}{*}{ Wednesday } & 0.0149 & $-0.0003^{* *}$ & $0.1867^{* *}$ & $0.6839^{* * *}$ \\
\hline & & $(0.590)$ & $(0.028)$ & $(0.038)$ & $(0.000)$ \\
\hline & \multirow{2}{*}{ Thursday } & $-0.0495^{* * *}$ & -0.0000 & 0.0198 & $-0.1848^{* * *}$ \\
\hline & & $(0.000)$ & $(0.758)$ & $(0.731)$ & $(0.000)$ \\
\hline & \multirow{2}{*}{ Friday } & $0.20^{* * *}$ & $-0.0005^{* * *}$ & 0.0267 & -0.0143 \\
\hline & & $(0.000)$ & $(0.000)$ & $(0.570)$ & $(0.887)$ \\
\hline \multirow{12}{*}{$\begin{array}{l}\text { Information } \\
\text { Technology }\end{array}$} & \multirow{2}{*}{ Monday } & -0.0152 & -0.0000 & $-0.1641^{*}$ & $0.1801^{*}$ \\
\hline & & $(0.605)$ & $(0.897)$ & $(0.083)$ & $(0.098)$ \\
\hline & \multirow{2}{*}{ Tuesday } & $-0.0383^{* * *}$ & $-0.0005^{* * *}$ & -0.0546 & $-0.3804^{* * *}$ \\
\hline & & $(0.006)$ & $(0.002)$ & $(0.550)$ & $(0.000)$ \\
\hline & \multirow{2}{*}{ Wednesday } & $-0.1293^{* * *}$ & $-0.0003^{*}$ & 0.0942 & $0.4205^{* * *}$ \\
\hline & & $(0.000)$ & $(0.092)$ & $(0.454)$ & $(0.000)$ \\
\hline & \multirow[t]{2}{*}{ Thursday } & -0.0211 & 0.0002 & $0.1448^{*}$ & 0.0131 \\
\hline & & $(0.368)$ & $(0.122)$ & $(0.064)$ & $(0.889)$ \\
\hline & \multirow{2}{*}{ Friday } & $0.238^{* * *}$ & $-0.0008^{* * *}$ & -0.0053 & -0.1124 \\
\hline & & $(0.000)$ & $(0.000)$ & $(0.889)$ & $(0.279)$ \\
\hline & \multirow{2}{*}{ Monday } & -0.0767 & -0.0000 & -0.0937 & 0.1475 \\
\hline & & $(0.003)$ & $(0.893)$ & $(0.169)$ & $(0.117)$ \\
\hline
\end{tabular}

Materials 
Table 9 (continued)

\begin{tabular}{|c|c|c|c|c|c|}
\hline Sector & Weekday & Recession & Uncertainty & Trades & $\begin{array}{c}\text { Bearish } \\
\text { Sentiment }\end{array}$ \\
\hline & \multirow{2}{*}{ Tuesday } & $-0.1057^{* * *}$ & -0.0002 & 0.0685 & $-0.675^{* * *}$ \\
\hline & & $(0.000)$ & $(0.133)$ & $(0.359)$ & $(0.000)$ \\
\hline & \multirow{2}{*}{ Wednesday } & 0.0179 & $-0.0002^{*}$ & 0.033 & 0.017 \\
\hline & & $(0.383)$ & $(0.056)$ & $(0.576)$ & $(0.830)$ \\
\hline & \multirow{2}{*}{ Thursday } & $-0.0971^{* * *}$ & -0.0001 & -0.08 & -0.0094 \\
\hline & & $(0.000)$ & $(0.136)$ & $(0.211)$ & $(0.894)$ \\
\hline & \multirow{2}{*}{ Friday } & $0.0514^{* *}$ & $-0.0002^{* *}$ & 0.0153 & 0.053 \\
\hline & & $(0.029)$ & $(0.027)$ & $(0.730)$ & $(0.475)$ \\
\hline \multirow{10}{*}{$\begin{array}{l}\text { Telecom } \\
\text { Services }\end{array}$} & \multirow{2}{*}{ Monday } & $-0.1479 * * *$ & $0.0004^{* * *}$ & 0.0158 & -0.1671 \\
\hline & & $(0.000)$ & $(0.003)$ & $(0.847)$ & $(0.112)$ \\
\hline & \multirow{2}{*}{ Tuesday } & $-0.1256^{* * *}$ & -0.0000 & 0.0833 & $-0.4154^{* * *}$ \\
\hline & & $(0.000)$ & $(0.855)$ & $(0.308)$ & $(0.000)$ \\
\hline & \multirow{2}{*}{ Wednesday } & $-0.0665^{* * *}$ & 0.0001 & 0.0718 & $-0.2016^{*}$ \\
\hline & & $(0.000)$ & $(0.315)$ & $(0.361)$ & $(0.077)$ \\
\hline & \multirow{2}{*}{ Thursday } & $-0.0439^{* * *}$ & -0.0001 & 0.0206 & -0.0246 \\
\hline & & $(0.000)$ & $(0.392)$ & $(0.770)$ & $(0.710)$ \\
\hline & \multirow{2}{*}{ Friday } & $-0.0435^{* *}$ & $-0.0007^{* * *}$ & 0.0265 & -0.0935 \\
\hline & & $(0.049)$ & $(0.000)$ & $(0.586)$ & $(0.269)$ \\
\hline \multirow{6}{*}{ Utilities } & \multirow{2}{*}{ Monday } & $0.0724^{*}$ & 0.0001 & -0.075 & 0.0837 \\
\hline & & $(0.054)$ & $(0.523)$ & $(0.408)$ & $(0.443)$ \\
\hline & \multirow{2}{*}{ Tuesday } & -0.0117 & -0.0002 & -0.0312 & -0.0405 \\
\hline & & $(0.657)$ & $(0.190)$ & $(0.765)$ & $(0.687)$ \\
\hline & \multirow{2}{*}{ Wednesday } & -0.0161 & $-0.0002^{*}$ & $0.2361^{* * *}$ & $0.3782^{* * *}$ \\
\hline & & $(0.447)$ & $(0.068)$ & $(0.003)$ & $(0.000)$ \\
\hline
\end{tabular}


Table 9 (continued)

\begin{tabular}{lccccc}
\hline Sector & Weekday & Recession & Uncertainty & Trades & $\begin{array}{c}\text { Bearish } \\
\text { Sentiment }\end{array}$ \\
\hline \multirow{2}{*}{ Thursday } & $0.1653^{* * *}$ & $3.74 \mathrm{e}-06$ & -0.0019 & 0.1019 \\
\cline { 2 - 5 } & $(0.000)$ & $(0.923)$ & $(0.954)$ & $(0.210)$ \\
\hline \multirow{2}{*}{ Friday } & $-0.0437^{*}$ & $-0.0009^{* * *}$ & 0.0899 & $-0.2553^{* * *}$ \\
\cline { 2 - 5 } & $(0.083)$ & $(0.000)$ & $(0.141)$ & $(0.004)$ \\
\hline
\end{tabular}

Notes: ${ }^{*}, * *$ and $* * *$ denote statistical significance at the $10 \%, 5 \%$ and $1 \%$ significance levels respectively. In each case, the marginal effect is presented followed by the associated $p$-value in parentheses.

\section{References}

Alagidede, Paul and Theodore Panagiotidis (2009). "Calendar anomalies in the Ghana stock exchange". In: Journal of Emerging Market Finance 8.1, pp. 1-23.

Alexakis, Panayotis and Manolis Xanthakis (1995). "Day of the week effect on the Greek stock market". In: Applied Financial Economics 5.1, pp. 43-50.

Baker, Scott R, Nicholas Bloom, and Steven J Davis (2016). "Measuring economic policy uncertainty". In: The Quarterly Journal of Economics 131.4, pp. 1593-1636.

Bampinas, Georgios, Stilianos Fountas, and Theodore Panagiotidis (2016). "The day-of-theweek effect is weak: Evidence from the European real estate sector". In: Journal of Economics and Finance 40.3, pp. 549-567.

Bampinas, Georgios, Konstantinos Ladopoulos, and Theodore Panagiotidis (2018). "A note on the estimated GARCH coefficients from the S\&P1500 universe". In: Applied Economics 50.34-35, pp. 3647-3653.

Berument, M Hakan and Nukhet Dogan (2012). "Stock market return and volatility: day-ofthe-week effect". In: Journal of Economics and Finance 36.2, pp. 282-302.

Bollerslev, Tim (1986). "Generalized autoregressive conditional heteroskedasticity". In: Journal of econometrics 31.3, pp. 307-327.

Brusa, Jorge, Pu Liu, and Craig Schulman (2003). "The weekend and reverse weekend effects: an analysis by month of the year, week of the month, and industry". In: Journal of Business Finance 8 Accounting 30.5-6, pp. 863-890.

Bush, Peter J and John E Stephens (2016). "The Return of the Monday Effect in European Currency Markets: An Empirical Analysis of the Impact of the Economic Crisis on Market Efficiency". In: International Journal of Finance \& Economics 21.3, pp. 241-246.

Cho, Young-Hyun, Oliver Linton, and Yoon-Jae Whang (2007). "Are there Monday effects in stock returns: A stochastic dominance approach". In: Journal of Empirical Finance 14.5 , pp. $736-755$.

Choudhry, Taufiq (2000). "Day of the week effect in emerging Asian stock markets: evidence from the GARCH model". In: Applied Financial Economics 10.3, pp. 235-242. 
Connolly, Robert A (1989). "An examination of the robustness of the weekend effect". In: Journal of Financial and quantitative Analysis 24.2, pp. 133-169.

Coutts, Andrew and Peter Hayes (1999). "The weekend effect, the stock exchange account and the financial times industrial ordinary shares index: 1987-1994". In: Applied Financial Economics 9.1, pp. 67-71.

Coutts, Andrew, Christos Kaplanidis, and Jennifer Roberts (2000). "Security price anomalies in an emerging market: the case of the Athens Stock Exchange". In: Applied Financial Economics 10.5, pp. 561-571.

Cross, Frank (1973). "The behavior of stock prices on Fridays and Mondays". In: Financial analysts journal 29.6, pp. 67-69.

Dickey, David A and Wayne A Fuller (1979). "Distribution of the estimators for autoregressive time series with a unit root". In: Journal of the American statistical association 74.366a, pp. 427-431.

Fama, Eugene F (1965). "The behavior of stock-market prices". In: The journal of Business 38.1 , pp. 34-105.

Fields, Morris J (1934). "Security prices and stock exchange holidays in relation to short selling". In: The Journal of Business of the University of Chicago 7.4, pp. 328-338.

Fishe, Raymond PH, Thomas F Gosnell, and Dennis J Lasser (1993). "Good news, bad news, volume, and the Monday effect". In: Journal of Business Finance 8 Accounting 20.6, pp. 881-892.

French, Kenneth R (1980). "Stock returns and the weekend effect". In: Journal of financial economics 8.1, pp. 55-69.

Gibbons, Michael R and Patrick Hess (1981). "Day of the week effects and asset returns". In: Journal of business, pp. 579-596.

Hansen, Peter, Asger Lunde, and James Nason (2005). Testing the significance of calendar effects. Working Paper 2005-02. Federal Reserve Bank of Atlanta.

Högholm, Kenneth and Johan Knif (2009). "The impact of portfolio aggregation on day-ofthe-week effect: Evidence from Finland". In: Global Finance Journal 20.1, pp. 67-79.

Jaffe, Jeffrey and Randolph Westerfield (1985). "The week-end effect in common stock returns: the international evidence". In: The journal of finance 40.2, pp. 433-454.

Kamath, Ravindra R, Rinjai Chakornpipat, and Arjun Chatrath (1998). "Return distributions and the day-of-the-week effects in the stock exchange of Thailand". In: Journal of Economics and Finance 22.2-3, pp. 97-107.

Keim, Donald B and Robert F Stambaugh (1984). "A further investigation of the weekend effect in stock returns". In: The journal of finance 39.3, pp. 819-835.

Kenourgios, Dimitris, Aristeidis Samitas, and Spyros Papathanasiou (2005). The day of the week effect patterns on stock market return and volatility: Evidence for the Athens Stock Exchange. Samos island July 15-17. Proceedings of the 2nd Applied Financial Economics (AFE) International Conference on Financial Economics.

Liu, Benjamin and Bin Li (2010). "Day-of-the-week effects: another evidence from top 50 Australian stocks". In: European Journal of Economics, Finance and Administrative Sciences 24, pp. $78-87$.

Lu, Xing and Han Gao (2016). "The Day of the Week Effect in Chinese Stock Market". In: The Journal of Asian Finance, Economics and Business 3.3, pp. 17-26.

Lucey, Brian M (2002). "Market direction and moment seasonality: evidence from Irish equities". In: Applied Economics Letters 9.10, pp. 657-664. 
Mbululu, D and C Chipeta (2012). "Day-of-the-week effect: Evidence from the nine economic sectors of the JSE". In: Investment Analysts Journal 2012.75, pp. 55-65.

Mehdian, Seyed and Mark J Perry (2001). "The reversal of the Monday effect: new evidence from US equity markets". In: Journal of Business Finance 63 Accounting 28.7-8, pp. 10431065.

Nelson, Daniel B (1991). "Conditional heteroskedasticity in asset returns: A new approach". In: Econometrica: Journal of the Econometric Society, pp. 347-370.

Pena, J Ignacio (1995). "Daily seasonalities and stock market reforms in Spain". In: Applied Financial Economics 5.6, pp. 419-423.

Penman, Stephen H (1987). "The distribution of earnings news over time and seasonalities in aggregate stock returns". In: Journal of financial economics 18.2, pp. 199-228.

Phillips, Peter CB and Pierre Perron (1988). "Testing for a unit root in time series regression". In: Biometrika 75.2, pp. 335-346.

Prince, Philip (1982). "Day of the week effects: hourly data". In: Manuscript, University of Chicago.

Rogalski, Richard J (1984). "New findings regarding day-of-the-week returns over trading and non-trading periods: a note". In: The Journal of Finance 39.5, pp. 1603-1614.

Rösch, Dominik M, Avanidhar Subrahmanyam, and Mathijs A Van Dijk (2016). "The dynamics of market efficiency". In: The Review of Financial Studies 30.4, pp. 1151-1187.

Santesmases, Migue (1986). "An investigation of the Spanish stock market seasonalities". In: Journal of Business Finance $\mathscr{E}$ Accounting 13.2, pp. 267-276.

Solnik, Bruno and Laurence Bousquet (1990). "Day-of-the-week effect on the Paris Bourse". In: Journal of Banking \& Finance 14.2-3, pp. 461-468.

Steeley, James M (2001). "A note on information seasonality and the disappearance of the weekend effect in the UK stock market". In: Journal of Banking \& Finance 25.10, pp. 1941-1956.

Sullivan, Ryan, Allan Timmermann, and Halbert White (2001). "Dangers of data mining: The case of calendar effects in stock returns". In: Journal of Econometrics 105.1, pp. 249286.

Taylor, Stephen J (1987). "Forecasting the volatility of currency exchange rates". In: International Journal of Forecasting 3.1, pp. 159-170.

Thaler, Richard H (1987). "Seasonal Movements in Security Prices II: Weekends, Holidays, Turn of the Month, and Intra-day Effects". In: Journal of Economic Perspectives 1.2, pp. 169-177.

Zhang, Jilin, Yongzeng Lai, and Jianghong Lin (2017). "The day-of-the-Week effects of stock markets in different countries". In: Finance Research Letters 20, pp. 47-62.

Zivot, Eric and Donald W K Andrews (2002). "Further evidence on the great crash, the oilprice shock, and the unit-root hypothesis". In: Journal of business 85 economic statistics 20.1, pp. 25-44. 


\section{Appendix}

Table 10 A selected summary of literature

\begin{tabular}{|c|c|c|c|}
\hline \multirow{2}{*}{$\begin{array}{l}\text { Author(s) } \\
\text { Panel } A: D a t\end{array}$} & Data & Methodology & Empirical Findings \\
\hline & aily seasonality in aggregate stock & indices & \\
\hline & $\begin{array}{l}\text { Daily returns of stock market } \\
\text { indexes of Japan (Nikkei Dow } \\
\text { 1970 - 1983), Canada (Toronto }\end{array}$ & & A weekend effect found in all markets and a \\
\hline Jaffe \& & Stock Exchange Index 1976 - & & Tuesday effect in Australia and Japan. In- \\
\hline $\begin{array}{l}\text { Westerfield } \\
\text { |1985 }\end{array}$ & $\begin{array}{l}\text { 1983), Australia (Statex Actu- } \\
\text { aries Index } 1973-1982 \text {, the }\end{array}$ & $\begin{array}{l}\text { ULS regression } \\
\text { analysis }\end{array}$ & $\begin{array}{l}\text { vestors actions in forelgn markets were inde- } \\
\text { pendent of those in the U.S. The Australian }\end{array}$ \\
\hline & $\begin{array}{l}\text { U.K. (Financial Times Ordinary } \\
\text { Share Index } 1950-1983 \text { ) and the } \\
\text { U.S. (S\&P500 } 1962-1983 \text { ) }\end{array}$ & & $\begin{array}{l}\text { pattern was partly explained by the time zone } \\
\text { difference with the U.S. }\end{array}$ \\
\hline $\begin{array}{l}\text { Alexakis \& } \\
\text { Xanthakis } \\
\text { |1995 }\end{array}$ & $\begin{array}{l}\text { A representative stock price in- } \\
\text { dex of the Athens Stock Ex- } \\
\text { change covering the period from } \\
\text { January } 1985 \text { to February } 1994 \text {, } \\
\text { investigated as a whole and di- } \\
\text { vided into two subperiods } 1985 \\
\text { - } 1987,1988 \text { - } 1994\end{array}$ & $\begin{array}{l}\text { EGARCH - M } \\
\text { model }\end{array}$ & $\begin{array}{l}\text { Positive returns for all days except Tuesday } \\
\text { for the whole period and first sub-period. The } \\
\text { second sub-period introduced negative Mon- } \\
\text { day returns along with Tuesdays. }\end{array}$ \\
\hline $\begin{array}{l}\text { Choudhry } \\
\text { |2000 }\end{array}$ & $\begin{array}{l}\text { Daily returns of } 7 \text { emerging } \\
\text { Asian stock markets from Jan- } \\
\text { uary } 1990 \text { to June } 1995\end{array}$ & $\begin{array}{l}\mathrm{GARCH}(1,1) \\
\text { model }\end{array}$ & $\begin{array}{l}\text { Significant negative Monday returns for In- } \\
\text { donesia, Malaysia and Thailand. Positive } \\
\text { Monday effect on volatility for all markets } \\
\text { except India. A possible explanation was a } \\
\text { spillover from the Japanese stock market but } \\
\text { no the settlement procedures. }\end{array}$ \\
\hline $\begin{array}{l}\text { Cho et al. } \\
2007\end{array}$ & $\begin{array}{l}\text { Daily returns of DJIA and } \\
\text { S\&P500 from } 1 / 1 / 1970 \text { - } \\
12 / 31 / 2004, \text { NASDAQ, Rus- } \\
\text { sell2000 and CRSP from } \\
1 / 1 / 1988-12 / 31 / 2004, \text { Nikkei } \\
225 \text { and FTSE } 100 \text { from } \\
1 / 1 / 1990-12 / 31 / 2004\end{array}$ & $\begin{array}{l}\text { OLS regres- } \\
\text { sion analysis, } \\
\text { Stochastic domi- } \\
\text { nance approach }\end{array}$ & $\begin{array}{l}\text { A Monday effect for most of the indexes. } \\
\text { After } 1987 \text { weakness of the effect for DJIA } \\
\text { and S\&P500 but remanence of significance for } \\
\text { broader based indices. }\end{array}$ \\
\hline $\begin{array}{l}\text { Alagidede } \\
\& \quad \text { Pana- } \\
\text { giotidis } \\
2009\end{array}$ & $\begin{array}{l}\text { Daily closing prices of the DSI } \\
\text { index on the GSE covering the } \\
\text { period between June } 15,1994 \text { to } \\
\text { April } 28,2004\end{array}$ & $\begin{array}{l}\text { OLS regres- } \\
\text { sion analy- } \\
\text { sis, GARCH, } \\
\text { EGARCH and } \\
\text { TGARCH, } \\
\text { rolling window } \\
\text { regression }\end{array}$ & $\begin{array}{l}\text { Out of the } 3 \text { weekdays that GSE market is } \\
\text { open, Friday showed the most significant re- } \\
\text { turns. This daily anomaly vanished within a } \\
\text { rolling framework. }\end{array}$ \\
\hline $\begin{array}{l}\text { Berument } \\
\& \quad \text { Dogan } \\
\qquad 2012\end{array}$ & $\begin{array}{l}\text { Daily data of } 9 \text { US indexes: } \\
\text { the equal- and value-weighted } \\
\text { NYSE, S\&P500, NASDAQ, } \\
\text { AMEX and equal-weighted } \\
\text { DOW from May 26, } 1952 \text { to } \\
\text { September } 29,2006\end{array}$ & $\begin{array}{l}\text { EGARCH-M } \\
\text { model }\end{array}$ & $\begin{array}{l}\text { When risk premium was supposed to be con- } \\
\text { stant across the days of the week, highest } \\
\text { (lowest) returns were observed on Fridays } \\
\text { (Mondays) and a positive risk premium was } \\
\text { found along with a leverage effect. Similar re- } \\
\text { sults were obtained when risk premium was } \\
\text { allowed to differ, but no findings sustained its } \\
\text { presence and constancy during the week. }\end{array}$ \\
\hline
\end{tabular}


Table 10 (continued)

\begin{tabular}{llll}
\hline Author(s) & Data & Methodology & Empirical Findings \\
\hline
\end{tabular}

Daily returns of 5 currency pairs: US dollar, Japanese yen,

Bush \& Great British pound, CanaStephens dian dollar and Australian dol2016 lar with Euro as base currency, studied in three periods 19992004, 2005-2009, 2010-2012

Daily stock returns of 28 market Zhang et al. indices in 25 countries (15 from 2017 emerging markets and 13 from developed ones). Data range from 1990 to 2016

Panel B: Disappearance of daily anomalies

Daily returns for the S\&P500, the equal- and value-weighted Connolly 1989 CRSP indexes covering the period between the first trading day in 1963 and the last one in 1983

Coutts UK stock market data of FT 30 \& Hayes beginning from June 8, 1979 till 1999 December 31, 1994

Steeley Daily returns of FTSE100 dur2001 ing April 1991-May 1998

Daily closing prices for 5 major US indices DJCOMP, Mehdian NYSE, S\&P500, NASDAQ, \& Perry RUSSELL2000 from June 4, 2001 1964 to February 6, except for RUSSELL in which start date is the 1998 January 2nd, 1979

Panel C: Sectoral focus

Daily returns of the Madrid stock exchange index and 40 Santesmases stocks divided into 3 groups 1986

(banks and investments, utilities and industrial stocks) covering January 1979-December 1983

Weak evidence ( $1 / 5$ currency pairs) of MonOLS regression day effect in the first two sub-periods. Reapanalysis pearance of the anomaly after the global economic crisis $(3 / 5)$

GARCH model, rolling sample method, calendar effect performance ratio

OLS regression analysis with sample size-adjusted critical F-values and error normality tests, M-distribution free estimators, $\operatorname{GARCH}(1,1)$

OLS regression analysis

OLS regression analysis

OLS regression Significant negative average Monday returns analysis, Chow were found over the whole sample. The patBreakpoint tern was unstable over the entire period, but Tests, Recur- stable in two subperiods: pre-1987 and postsive Coefficient 1987. Significant reversal of the Monday efEstimations fect over time for the large-cap stocks.

OLS regression analysis No day of the week effect detected rather a (F-statistic)

Day-of-the-week effects did exist in all markets examined. Robust results across periods. Calendar anomalies did not vanish for 6 indices chosen when they were measured in US dollars.

The weekend effect was weaker than suspected before and disappeared in the mid1970s. A correction for heteroskedasticity and autocorrelation weakened the abnormality until the mid-1970s.

A weekend effect was present but weaker than was previously documented. Settlement procedures partly explained the pattern.

A weekend effect was absent. A combined Monday and Friday effect was found on the bad news data. Stronger evidence of anomaly on announcement-bad news days. Possible explanation was the surprise seasonality. turn of the year effect. 
Table 10 (continued)

\begin{tabular}{|c|c|c|c|}
\hline Author(s) & Data & Methodology & Empirical Findings \\
\hline PeNa 1995 & $\begin{array}{l}\text { Daily returns of the Madrid } \\
\text { stock market index (IGBM) and } \\
7 \text { sectorial portfolios during Jan- } \\
\text { uary 1986-March } 1993\end{array}$ & $\begin{array}{l}\text { OLS regression } \\
\text { analysis (Ljung- } \\
\text { Box, t-stat., } \\
\text { F-stat.) }\end{array}$ & $\begin{array}{l}\text { Positive average Monday returns before the } \\
\text { CATS but no daily structures after the re- } \\
\text { form. }\end{array}$ \\
\hline $\begin{array}{l}\text { Kamath, } \\
\text { Chakorn- } \\
\text { pipat \& } \\
\text { Chatrath } \\
1998\end{array}$ & $\begin{array}{l}\text { Daily prices of the Thailand's } \\
\text { Stock Exchange (SET) and its } \\
\text { ten sector indices for the period } \\
\text { January 1980-December } 1994\end{array}$ & $\begin{array}{l}\text { OLS and } \\
\operatorname{GARCH}(1,1) \\
\text { model }\end{array}$ & $\begin{array}{l}\text { Significant negative Monday returns and pos- } \\
\text { itive Friday returns for all } 11 \text { indices exam- } \\
\text { ined. Robust results across the } 2 \text { methods } \\
\text { employed. }\end{array}$ \\
\hline $\begin{array}{l}\text { Coutts } \\
\text { Kaplanidis } \\
\text { \& Roberts } \\
2000\end{array}$ & $\begin{array}{l}\text { Daily data prices of the Athens } \\
\text { Stock Exchange general index } \\
\text { (ASE) and its } 3 \text { major indices: } \\
\text { banking, insurance and leasing } \\
\text { from October } 1986 \text { through Au- } \\
\text { gust } 1996\end{array}$ & $\begin{array}{l}\text { OLS regression } \\
\text { analysis }\end{array}$ & $\begin{array}{l}\text { Day of the week effect in market and bank- } \\
\text { ing sector for the whole period and 2nd sub- } \\
\text { period (1991-1996). For the 1st one, negative } \\
\text { Tuesday and Wednesday average return were } \\
\text { observed. Positive January returns for all in- } \\
\text { dices except for insurance and strong evidence } \\
\text { for holiday effect. }\end{array}$ \\
\hline
\end{tabular}

Daily percentage returns of the Irish stock market index (ISEQ), the corresponding index of to-

Lucey tal returns (ISEQR) from Jan- F, Kruskal- Evidence suggested a Wednesday effect in 2002 uary 1988 to December 1998 Wallis and two sectoral indices: fi- Levene tests kets. nancial (ISEFIN) and industrial (ISEGEN) from February 1989 to December 1998

Daily data from 2 market indices Brusa et al. DJIA, NYSE, 4 major NYSE OLS regression 2003 industry indices and 20 industry analysis indices from 1966 to 1996

Closing prices of the Athens Stock Exchange general index Kenourgios, for ten years January 1995 to Samitas \& December 2004, and five maPapathana- jor indices for the two subperisiou 2005 ods 1995-2000 (banking, insur-

$\operatorname{GARCH}(1,1)$ \& modified $\operatorname{GARCH}(1,1)$
Reverse (traditional) weekend effect in the 2 market indices for the post (pre) - 1988 subperiod. Similar results for the industry indices even when the month of the year and week of the month effects were accounted for.

An intense existence of the day of the week effect in returns and both returns and volatil- ity for the whole period and 1st sub-period. Weakness of the anomaly for the 2nd one, except for the general and FTSE-40 indices. ance, miscellaneous) and 20012004 (FTSE-20, FTSE-40)

Daily data from the Finnish OMX Cup stock market index Unconditional: and 4 sector indices with 4 corre- ANOVA F-test,

Hogholm \& sponding firms' data: Basic Ma- Kruskal-Wallis

In the pre-euro period, intraweek patterns in the volatility were found for the market and 2 of the firms' indices. During the post-euro Knif 2009 terials (Huhtamaki), Consump- test, Brown tion Goods (Kesko), Forestry Forsythe test and Paper (UPM) and Industri- Conditional: als (Kone) from April 1993 to EGARCH model period, such patterns were found in both the mean for 3 series and the variance for all 4 industry indices.

June 2006 
Table 10 (continued)

Author(s) Data Methodology

Daily closing stock returns of the

Liu \& Li top 49 Australian companies for

2010 the period January 2, 2001-June

t-tests

30,2010

Mbululu Daily closing value-weighted in-

\& Chipeta dex values for 9 sectors of JSE Kolmogorov-

2012 from July 3, 1995 to May 13, Smirnov test 2011

Unconditional:

Kruskal-Wallis

Daily returns of a global, a eu-

Bampinas ropean and 12 national (euro-

et al. 2016 pean) securitized real estate indices from January 15, 1990 to May 11, 2010 test for ranks, modified Levene Conditional: $\operatorname{GARCH}(1,1)$, GJR-GARCH, EGARCH, Empirical Findings

Largest mean returns on Mondays for 15 companies (mostly in materials and energy sectors). Larger the Monday returns than returns in any other days for 6 companies.

Day-of-the-week effects were absent in all indices, except for the basic materials sector where a Monday effect was present.

rolling window

regression 